\title{
Quantitative reconstruction of late Holocene surface evolution on an alpine debris-flow fan
}

Peter Schürch ${ }^{1 *}$, Alexander L. Densmore ${ }^{1 \dagger}$, Susan Ivy-Ochs ${ }^{2}$, Nick J. Rosser ${ }^{1}$, Florian Kober ${ }^{3}$, Fritz Schlunegger ${ }^{4}$, Brian McArdell ${ }^{5}$, and Vasili Alfimov²

${ }^{1}$ Institute of Hazard, Risk, and Resilience and Department of Geography, Durham University, Durham DH1 3LE, UK

${ }^{2}$ Laboratory of Ion Beam Physics, ETH Zürich, Otto-Stern-Weg 5, 8093 Zürich, Switzerland

${ }^{3}$ Institute of Geology, ETH Zürich, Sonneggstrasse 5, 8092 Zürich, Switzerland

${ }^{4}$ Institute of Geological Sciences, University of Bern, Baltzerstrasse 1+3, 3012 Bern, Switzerland

${ }^{5}$ Swiss Federal Institute for Forest, Snow, and Landscape Research WSL, Zürcherstrasse 111, 8903 Birmensdorf, Switzerland

*Now at Geosfer AG, 8570 Weinfelden, Switzerland
${ }^{\dagger}$ Corresponding author; email a.I.densmore@dur.ac.uk

\section{Abstract}

Debris-flow fans form a ubiquitous record of past debris-flow activity in mountainous areas, and may be useful for inferring past flow characteristics and consequent future hazard. Extracting information on past debris flows from fan records, however, requires an understanding of debrisflow deposition and fan surface evolution; field-scale studies of these processes have been very limited. In this paper, we document the patterns and timing of debris-flow deposition on the surface of the large and exceptionally active Illgraben fan in southwestern Switzerland. We use terrain analysis, radiocarbon dating of sediment fill in the Illgraben catchment, and cosmogenic ${ }^{10} \mathrm{Be}$ and ${ }^{36} \mathrm{Cl}$ exposure dating of debris-flow deposits on the fan to constrain the temporal evolution of the sediment routing system in the catchment and on the fan during the past 3200 years. We show that the fan surface preserves a set of debris-flow lobes that were predominantly deposited after the occurrence of a large rock avalanche near the fan apex at about 3200 years ago. This rock avalanche shifted the apex of the fan and impounded sediment within the Illgraben catchment. Subsequent evolution of the fan surface has been governed by both lateral and radial shifts in the 
active depositional lobe, revealed by the cosmogenic radionuclide dates and by cross-cutting geometrical relationships on the fan surface. This pattern of frequent avulsion and fan surface occupation provides field-scale evidence of the type of large-scale compensatory behavior observed in experimental sediment routing systems.

Keywords: fans; lobes; avulsion; debris flows; Switzerland; cosmogenic radionuclide dating

\section{Introduction}

Debris flows are a ubiquitous process in mountain environments around the world, and represent a major physical hazard to populations and infrastructure. Deposition of sediment by repeated flows results in the construction of debris-flow fans that can potentially record information on past flow size, timing, composition, and depositional pattern (Schumm et al., 1987; Harvey, 2011). Such fans are therefore a potentially powerful archive of debris-flow processes (e.g., Whipple and Dunne, 1992; Dühnforth et al., 2007; d’Arcy et al., 2015; de Haas et al., 2015a, 2015b), hazard (e.g., Hubert and Filipov, 1989; Helsen et al., 2002; Stoffel et al., 2008a; Arattano et al., 2010; de Scally et al., 2010), and sediment supply (e.g., McDonald et al., 2003; Dühnforth et al., 2008; Hornung et al., 2010; Savi et al., 2014). Reading that archive, however, and extracting quantitative information about past debris flows, requires that we understand the pattern and timing of debris flow deposition on fans so that the evolution of the fan can be reconstructed.

Much recent work on fluvial fans and fan deltas has shown that they grow and evolve by a sequence of autogenic avulsion, fan-head incision or trenching, and backfilling (e.g., Kim and Muto, 2007; Nicholas and Quine, 2007; Powell et al., 2012; Reitz and Jerolmack, 2012; van Dijk et al., 2009,2012 ), leading to migration of the active locus of deposition in space and time and filling of the available accommodation (Straub et al., 2009). This autogenic sequence can be modified or overprinted by allogenic forcing of fan development caused for example by large landslides or rock avalanches that drive external variations in sediment supply (e.g., Davies and Korup, 2007; Korup et al., 2010). By comparison, there has been little work on whether fans built by debris flows share this evolutionary model, or how they are affected by external events such as large landslides. 
Debris-flow fans are known to occupy different depositional lobes over time (Suwa and Okuda, 1983; Blair and McPherson, 1994; Stoffel et al., 2005; Dühnforth et al., 2007; Ventra and Nichols, 2014; d'Arcy et al., 2015), and switching between lobes has been linked to internal and external controls on fan development (Dühnforth et al., 2008; Ventra and Nichols, 2014). Schumm et al. (1987) and de Haas et al. (2016) documented cyclic alternations of avulsion, channelization, and backstepping of the active depocenter on experimental debris-flow fans, and de Haas et al. (2016) argued that debris-flow fans are therefore likely governed by the same large-scale compensatory behavior as fluvial fans and fan deltas, albeit via different physical processes. To date, however, there are very few well-documented and well-dated examples of this behavior on active field-scale debris-flow fans.

Studies of debris-flow fan surface evolution to date have tended to focus on arid environments such as the western USA, where vegetation and post-emplacement sediment reworking are minimized and primary debris-flow depositional features are more easily preserved (e.g., Whipple and Dunne, 1992; Kim and Lowe, 2004; Staley et al., 2006; Frankel and Dolan, 2007; Dühnforth et al., 2007). Despite the frequency of debris flows in more humid environments such as the Swiss Alps (Hürlimann et al., 2003; Schlunegger et al., 2009), quantitative reconstruction of the timing and patterns of deposition on alpine debris-flow fans remains fairly limited. A number of studies have used dendrochronology to establish the timing and magnitude of debris flows on fans in the Swiss Alps (e.g., Stoffel et al., 2005, 2008a, 2008b, 2014; Bollschweiler and Stoffel, 2010; Stoffel, 2010; Arbellay et al., 2010). This approach typically is limited to the last few hundred years (Bollschweiler and Stoffel, 2010) and cannot therefore capture the evolution of the fan surface over Holocene time scales. It is therefore not clear whether alpine debris-flow fans record similar patterns of avulsion, channelization, and backstepping, nor what time scales are required to completely resurface a large fan in these settings.

Here, we begin to address these knowledge gaps by documenting the evolution of the Illgraben fan, in southwestern Switzerland, as recorded by the debris-flow deposits that are visible on the fan surface. The Illgraben is one of the largest fans in the Swiss Alps and is exceptionally active, with 
an average of 3-5 debris flows per year (Hürlimann et al., 2003; McArdell et al., 2007; Schlunegger et al., 2009). The characteristics, morphology, and patterns and mechanisms of erosion and deposition in these flows have been very well documented (McArdell et al., 2007; Berger et al., 2011; Schürch et al., 2011), as have their contributions to catchment-scale sediment transfer (Schlunegger et al., 2009; Bennett et al., 2013, 2014; Burtin et al., 2014). Previous studies of the fan, however, are limited to quantification of the near-surface stratigraphy (Franke et al., 2014) and short-term evolution of the fan surface as recorded by dendrochronology (Stoffel et al., 2008a; Arbellay et al., 2010). To understand the longer-term development of the entire fan surface, we combine geomorphic mapping and analysis of the fan surface, using high-resolution digital topographic data, with the first systematic study of post-glacial depositional ages using in situ cosmogenic radionuclide exposure dating on an alpine debris-flow fan. While these techniques have previously been combined and applied to arid-region fans (e.g., Dühnforth et al., 2007), this is (to our knowledge) the first application to a fan in a more geomorphically active setting such as the Alps.

\section{Field site}

The Illgraben catchment (Fig. 1) is located on the southern flank of the Rhone Valley, within the canton of Wallis in southwestern Switzerland. The catchment covers an area of ca. $9.5 \mathrm{~km}^{2}$ and feeds a debris-flow fan with a radius of $\sim 2 \mathrm{~km}$ that has developed on the floor of the Rhone Valley. Two bedrock units of different lithologies, both highly fractured, dominate the catchment (Gabus et al., 2008): the northwestern (left) bank of the Illgraben is underlain by Upper Triassic dolomites and marbles, whilst the southeastern (right) bank is mainly underlain by Lower Triassic quartzites (Fig. 1). Both units are steeply dipping to the southeast.

Sediment is supplied to the IIlgraben catchment-fan system by frequent landslides and debris flows within the catchment, as documented by Schlunegger et al. (2009) and Bennett et al. (2012). This material accumulates within the trunk channel of the Illgraben and is re-entrained in debris flows that reach the fan (Bennett et al., 2013) and in most cases the Rhone River (Schlunegger et al., 2009; Berger et al., 2011; Schürch et al., 2011). Bennett et al. (2014) showed that episodicity in 
sediment delivery to the fan, at least on decadal time scales, can be understood as a product of stochastic variations in sediment supply and of a critical runoff necessary for debris-flow generation. Delivery of sediment to the fan is complicated by the presence of at least two large rock avalanche deposits $\left(>10^{6} \mathrm{~m}^{3}\right)$. The most recent rock avalanche, referred to herein as the rock avalanche in the upper Illgraben, occurred in 1961 and transferred a volume of $\sim 3.5 \times 10^{6} \mathrm{~m}^{3}$ of material to the Illgraben trunk channel. An older, previously-undated rock avalanche deposit is located near the fan apex (Gabus et al., 2008). Given its position, it is possible that its emplacement has (i) directly affected patterns of deposition on the Illgraben fan surface, and (ii) temporarily impounded sediment within the catchment upstream of the deposit, leading to timevariable sediment supply and potentially causing formation or abandonment of lobes on the fan. By determining the time of emplacement of the rock avalanche, compared to depositional ages of sediments in the catchment and debris-flow deposits on the fan surface, we should be able to untangle these potential effects.

Badoux et al. (2008) estimated the volume of the Illgraben fan to be $\sim 500 \times 10^{6} \mathrm{~m}^{3}$. The currently active channel follows the approximate centerline of the fan and separates the forested western half from agricultural and developed land on the eastern half. The active channel is incised by up to $20 \mathrm{~m}$ into the present-day fan surface. Various authors have contributed to build a record of historic and prehistoric debris-flow events that are preserved on the fan surface. A dendrogeomorphic analysis of trees affected (but not removed) by debris flows (Stoffel et al., 2008b) reported six events that affected areas along the active channel between 1793 and 1931 , but did not identify an 1868 event mentioned by Marchand (1871). Rickenmann et al. (2001) documented a total of 46 debris flows between 1932 and 2000, with a gap after the construction of a sediment retention dam (checkdam 1 in Fig. 1) during the early 1970s in response to the 1961 rock avalanche. For the period up to the year 2000 , estimates of debris flow volumes are uncertain; the largest reported event occurred on 3 June 1961 in response to the rock avalanche earlier in the same year and was estimated to have had a volume of ca. 2.5-5.0 x $10^{5} \mathrm{~m}^{3}$ (Badoux et al., 2008). Since 2000 the Swiss Federal Institute for Forest, Snow and Landscape Research (WSL) has maintained a debris-flow observation station (Hürlimann et al., 2003) at the toe of the 
fan (Fig. 1) where debris-flow volumes can be estimated from direct observation (McArdell et al., 2007; Schlunegger et al., 2009; Berger et al., 2011). The 35 flows recorded from 2000 to 2009 delivered a median total of $\sim 10^{5} \mathrm{~m}^{3}$ of sediment to the fan per year (McArdell and Berger, 2010). Seasonal debris-flow activity peaks between May and October in response to convective rainstorms (McArdell et al., 2007; Badoux et al., 2008; Schlunegger et al., 2009). A review of all reported debris-flow events and an assessment of topographic maps of the area since 1845 (Dufour, 1845; Siegfried, 1886, 1907, 1915, 1924, and 1933) indicate that since 1793 no major avulsion has occurred and that the presently-active channel down the centerline of the fan was already established, and has been recurrently active, since before that time.

Debris-flow deposit ages and sedimentation rates on the fan are not well constrained. Bardou et al. (2003) and Gabus et al. (2008) reported radiocarbon dating of the same samples of buried soils collected from the 'lower part of the cone' along the present-day channel, but exact sample locations were not given. These data suggest deposition of $5 \mathrm{~m}$ over $1231 \pm 70$ years and $2 \mathrm{~m}$ over $1354 \pm 60$ years at the sample locations but cannot be extrapolated to the fan as a whole. Franke et al. (2014) documented several distinct radar facies units in the upper 9-10 m of the fan but lacked age control on these deposits. The only constraint on the total age of the fan comes from Ivy-Ochs et al. (2008), who argued that the Rhone Valley at the position of the Illgraben fan has probably remained ice-free since the end of the Gschnitz Stadial at 17-16 ky. The present-day Illgraben fan therefore began to accumulate after that time.

\section{Methods}

\subsection{Terrain analysis}

To establish the spatial pattern of deposition on the fan, we mapped both the undated rock avalanche deposit near the fan apex and depositional lobes on the debris-flow fan in the field (Fig. 2). Field mapping was cross-checked against a LiDAR-derived DEM (the Swisstopo DTM-AV) with a 2-m resolution and a $1 \sigma$ elevation uncertainty of $\pm 0.5 \mathrm{~m}$, based on a raw point density of 1 point per $2 \mathrm{~m}^{2}$. To help in distinguishing different fan lobes, we detrended the DEM of the fan area by subtracting a second-order polynomial surface from the DEM within the area outlined in Fig. 1. We 
then used a semiquantitative description of the surface morphology (Dühnforth et al., 2007) in order to distinguish between different depositional lobes. This process included the surface roughness over channel-like length scales $(\sim 10 \mathrm{~m})$, the dimensions of channels and levees, and the presence and size of boulders. The boundaries of fan lobes and their relative chronology were established with cross-cutting relationships between channels and downlapping of depositional lobes onto older surfaces, which has produced traceable topographic steps on the fan surface. Distinction of lobes in the distal parts of the fan became increasingly difficult and speculative (e.g., Dühnforth et al., 2007), so our field mapping was limited to a radial distance of $\sim 1.2 \mathrm{~km}$ from the fan apex.

Fill terraces are present within the Illgraben catchment (Schlunegger et al., 2013), upstream of the rock avalanche deposit near the head of the Illgraben fan (Fig. 1). It is important to understand the volume and age of this sediment as well as the potential volume of sediment that could have been impounded by the rock avalanche, as these may affect the evolution of the fan surface. To determine the extent and amount of sediment that is still present, we mapped discontinuous fill terraces between the rock avalanche deposit and checkdam 1 on both channel banks (Fig. 1) in the field. These terraces pass downstream into, are coplanar with, and are likely coeval with fan lobe L9 on the right bank of the Illgraben channel (Fig. 2). We then manually picked elevation samples from the DEM to represent these terraces and lobe L9 and interpolated a third-order polynomial surface (Fig. 3) to reconstruct a lower fill surface aligned with the present-day active fan surface.

We calculated a minimum volume for the rock avalanche deposit at the fan apex from the DEM based on the mapped outline of the deposit (Fig. 2), a minimum thickness calculated from the lowest outcrop of the deposit at $748 \mathrm{~m}$ asl (marked with a star in Fig. 2), and an assumed horizontal, planar base. To determine the potential accommodation that was created behind the rock avalanche, we then shifted the lower fill surface vertically upward to match the top of the rock avalanche deposit, forming an upper bounding fill surface (Fig. 3). This approach assumes that the channel bed slope has been more or less constant since emplacement of the rock avalanche, that 
the available accommodation was completely filled, and that the top of the rock avalanche deposit has not undergone substantial erosion; if there has been erosion of the deposit, then our estimated accommodation is a minimum. The potential accommodation was then calculated as the difference between the DEM and the upper bounding fill surface, using an assumed downstream limit as indicated in Fig. 3. We chose the downstream limit of our calculation where the valley shape is still well defined.

Finally, to determine the potential effect of the rock avalanche on depositional patterns on the fan, as well as evidence of radial shifts in the active locus of deposition, we looked for signs that the apex of the fan has shifted over time. We assumed that channels on the fan surface must radiate from the fan apex and that the channels follow approximately linear trends, as is commonly observed on active debris-flow fans (e.g., Whipple and Dunne, 1992; Dühnforth et al., 2007). Thus, by mapping channels or channel fragments on individual fan lobes and projecting them back toward the catchment outlet, we can visualize the likely approximate position of the fan apex during deposition of that lobe. To do this, we identified 75 channel fragments across different lobes on the fan surface and calculated a linear trend for each fragment by connecting its start and end points. We projected these trend lines toward the head of the fan and into a search area for the reconstruction of the apex. Within this area, we defined a regular raster with a node every $10 \mathrm{~m}$ and counted the number of channel trend lines that intersected within a circle of $150-\mathrm{m}$ radius around each node. This radius approximately matches the width of the catchment outlet and allowed us to visualize large-scale shifts in apex position while accounting for the fact that debrisflow channels are not perfectly linear.

\subsection{Cosmogenic exposure dating of boulders on the fan surface}

Absolute depositional ages from the Illgraben fan surface were derived from in situ cosmogenic exposure dating of quartzite and carbonate boulders. We selected a total of 16 boulders for exposure dating: 12 quartz-rich boulders for dating with ${ }^{10} \mathrm{Be}$ and 4 carbonate boulders for dating with ${ }^{36} \mathrm{Cl}$, distributed among the mapped fan lobes (Tables 1 and 2). We chose boulders that were as large as possible in diameter (1.5-6.0 m), that had an upper surface within $25^{\circ}$ of horizontal to 
minimize shielding effects (Dunne et al., 1999), and that appeared to be situated in their original depositional context - e.g., embedded in a recognizable debris flow levee or snout rather than isolated on the fan surface. For example, we avoided isolated boulders on fan lobes below the north flank of the Gorwetsch Grat (Fig. 1), as they may have originated from rockfall after fan surface deposition. The boulders consisted of sericitic quartzite, white quartzite, marble, and dolomite. Two sampled boulders (samples IG46 and IG60) were located on the rock avalanche deposit near the fan apex and were sampled to provide a minimum age of rock avalanche emplacement. At each location, we collected $>0.5 \mathrm{~kg}$ of material from the uppermost $4 \mathrm{~cm}$ of the surface and as far from the boulder edges as possible, using a hammer and chisel. Sample positions were surveyed with a hand-held GPS receiver and were verified and adjusted against the DEM and the 1:25,000 topographic map. Locations near channels or prominent topographic features are accurate to about $\pm 2 \mathrm{~m}$ after this adjustment, while locations in unstructured terrain were more difficult to verify and are accurate to about $\pm 10 \mathrm{~m}$. At each location we measured the angle to the local horizon at $>10$ azimuths with a hand-held compass and clinometer to calculate the shielding correction (Tables 1 and 2).

Sample preparation and ${ }^{10} \mathrm{Be}$ and ${ }^{36} \mathrm{Cl}$ accelerator mass spectrometry (AMS) measurements were carried out at the Laboratory of Ion Beam Physics at ETH Zürich, Switzerland. For ${ }^{10} \mathrm{Be}$, standard procedures were followed to separate pure quartz from the $0.2-0.8 \mathrm{~mm}$ fraction of the bulk rock samples and for the purification of Be (Ivy-Ochs and Kober, 2008). ${ }^{10} \mathrm{Be} /{ }^{9} \mathrm{Be}$ ratios were measured with the $6 \mathrm{MV}$ tandem accelerator at ETH Zürich relative to ETH in-house standard S2007N (Christl et al., 2013), which is fixed to the 07KNSTD standard of Nishiizumi et al. (2007). The weighted average ${ }^{10} \mathrm{Be} /{ }^{9} \mathrm{Be}$ long-term, full-process blank ratio of $2.60 \pm 0.43 \times 10^{-15}$ was subtracted from the measured sample ratios. Exposure ages were calculated with the Cronus Earth ${ }^{10} \mathrm{Be}$ exposure age calculator v. 2.2 (Balco et al., 2008, and updates) using a half-life of 1.39 My and a sea level, high-latitude spallation production rate of $3.87 \pm 0.19{ }^{10} \mathrm{Be}$ atoms $\mathrm{g}^{-1} \mathrm{y}^{-1}$ with $\mathrm{Lm}$ scaling (Balco et al., 2009). A rock density of $2.65 \mathrm{~g} \mathrm{~cm}^{-3}$ was assumed for the quartzites. 
using procedures described by Ivy-Ochs et al. (2004), which is based on the method of Stone et al. (1996). Samples were prepared using isotope dilution (Ivy-Ochs et al., 2004) with a carrier of 99.9\% pure ${ }^{35} \mathrm{Cl}$ from Oak Ridge Labs. The $\mathrm{Cl}$ ratios were measured with the $6 \mathrm{MV}$ tandem accelerator at $\mathrm{ETH}$ Zürich. ${ }^{36} \mathrm{Cl} / \mathrm{Cl}$ sample ratios were normalized to the $\mathrm{ETH}$ internal standard $\mathrm{K} 382 / 4 \mathrm{~N}$ with a value of ${ }^{36} \mathrm{Cl} / \mathrm{Cl}=17.36 \times 10^{-12}$ (Christl et al., 2013). Stable ${ }^{37} \mathrm{Cl} /{ }^{35} \mathrm{Cl}$ ratios were normalized to the natural ratio of ${ }^{37} \mathrm{Cl} /{ }^{35} \mathrm{Cl}=31.98 \%$. Measured sample ratios were corrected for a full process chemistry blank ratio of $5.6 \times 10^{-15}$, which amounted to a correction of $<13 \%$ for the four samples. The ${ }^{36} \mathrm{Cl}$ exposure ages were calculated based on the parameters given in detail in Alfimov and Ivy-Ochs (2009), with a Ca spallation production rate of $54.0 \pm 3.5^{36} \mathrm{Cl}$ atoms g $\mathrm{g}^{-1}$ (Stone et al., 1996, 1998). Major and minor element (B, Sm, U, Th) concentrations (Table 3) were used to calculate the sample-specific production rates following the procedures in Alfimov and IvyOchs (2009). A rock density of $2.4 \mathrm{~g} \mathrm{~cm}^{-3}$ was assumed for the limestone samples. No corrections were made for rock surface erosion, vegetation cover, or snow coverage.

\subsection{Radiocarbon dating of wood samples}

We determined the chronology of sediment impounded in the catchment, upstream of the rock avalanche deposit, with radiocarbon ages established on three pieces of wood (samples S1, S2, and S3) found in sediment exposed along the Illgraben channel between checkdams 1 and 10 (Fig. 3). These samples were embedded in a poorly sorted, massive, matrix-rich boulder diamict on the right bank of the Illgraben channel. The samples were located topographically higher than the lower fill surface that is continuous with fan lobe $L 9$, but topographically lower than the upper fill surface that is continuous with the top of the rock avalanche deposit (Figs. 3 and 4). The samples were prepared and dated in the Radiocarbon Lab of the Physical Institute of the University of Bern, Switzerland. Radiocarbon dates were calibrated with Oxcal 4.2 (Bronk Ramsey, 2009) using the IntCal13 data set (Reimer et al., 2013).

\section{Results}

\subsection{Geomorphic mapping and terrain analysis}

\subsubsection{Lobe deposits}


The surface of the Illgraben fan was divided in the field into the rock avalanche deposit (RA, Fig. 2) and 11 distinct depositional lobes ( $\mathrm{L} 1-\mathrm{L} 11$, numbered in decreasing order of relative age). Crosscutting relationships show that the rock avalanche was emplaced after deposition of lobe $L 1$ and clearly before the deposition of lobe L6 (Fig. 2). While lobes L2, L3, and L4 can be differentiated on the basis of their surface morphology, their relative chronology and their age relationships with the rock avalanche cannot be determined with certainty from mapping alone. Likewise, the relative chronology of the lobes on the eastern and western sides of the active channel cannot be compared directly because of a lack of contacts and cross-cutting relationships. Thus, the lobe numbering represents our best estimate of the relative timing of deposition across the fan surface.

Lobe L1 consists of one distinct channel, 15-20 m wide and 1-2 m deep, and a number of boulders up to $4 \mathrm{~m}$ in diameter that form several distinct debris-flow snouts. The channel is clearly truncated by channels and levees of lobe L6 at its downstream end, and by the rock avalanche deposit at its upstream end. The rock avalanche deposit downlaps onto lobe $L 1$, and the contact is marked by a distinct concave break in slope.

Lobe L2 consists of a series of short, subparallel channels, $\sim 10 \mathrm{~m}$ wide and 1-2 m deep, with welldefined boulder levees. Most of the boulders in the levees are 1-2 $\mathrm{m}$ in diameter but range up to 4 $\mathrm{m}$. At the upstream end of L2, the channels are blocked by snouts of lobe L6, which downlaps onto the older lobe L2.

Lobe L3 is dominated by a long and distinct channel, $\sim 15 \mathrm{~m}$ wide and 1-3 m deep, confined between broad and relatively smooth levees with no large boulders (all $<1 \mathrm{~m}$ ). The upstream end of this channel is clearly truncated by deposits of lobe L7, which downlap onto L3. Two shorter channel fragments, which are possibly part of a single channel, can be found to the east of the main L3 channel, and are truncated by deposits of lobe L10.

Lobe L4 consists of a single wide, shallow, poorly-defined channel, which is truncated and surrounded by deposits of lobe L8. It appears to be limited to a small window surrounded by L8 deposits. No boulders are exposed, and the surface morphology outside the channel is smooth. Lobe L5 consists of a narrow deposit between the rock avalanche and lobe L1 in the east, and the talus slopes beneath the Gorwetsch Grat in the west (Fig. 1). The lobe is dominated by a single 
channel with well-defined boulder levees. The levees consist of rounded quartzite boulders of up to $4 \mathrm{~m}$ in diameter. Outside of this channel, and clearly distinct from it in terms of lithology and depositional geometry, are a number of scattered angular boulders of dolomite and marble (up to 3 $m$ in diameter), likely originating from isolated rockfalls from the Gorwetsch Grat. At its downstream end, lobe L5 is cross-cut and truncated by deposits of lobe L6.

Lobe L6 is poorly channelized in the proximal part and almost free of channels in the distal part. Numerous lobate deposits and snouts create a highly undulating surface with only rare boulders, generally $<0.5 \mathrm{~m}$ in diameter. This lobe clearly truncates older channels on lobes L1, L2, and L5. Lobe L7 consists of a number of channels that are up to $16 \mathrm{~m}$ wide and 1-3 $\mathrm{m}$ deep. They are lined by well-defined boulder levees with grain sizes of up to $2 \mathrm{~m}$. Channels in this lobe are truncated by deposits of L10.

Lobe L8 occupies most of the eastern half of the fan. Despite intensive agricultural land use and the construction of stone walls and irrigation systems, many individual debris-flow channel fragments can still be traced over distances of up to $100 \mathrm{~m}$, incised 1-2 m into the fan surface. However, the surface morphology is smooth, boulders are scarce, and the boundaries with lobes L4, L9, and L11 were difficult to map precisely. Lobe L8 is, however, clearly older than lobe L9, which downlaps onto L8 deposits. Except for the occurrence of a distinct feeder channel at the top, lobe L9 is smooth, largely unchannelized, and contains only a few boulders (up to $3 \mathrm{~m}$ in diameter) close to its downfan boundary.

Lobe L10 consists mainly of stacked lobate deposits and snouts, with a few boulders of up to $2 \mathrm{~m}$ in diameter but a generally smooth and unchanneled morphology. Its deposits truncate channels in lobes L2, L3, and L7.

Lobe L11, finally, forms the central axis of the fan and also contains the presently active channel. The width of the active channel decreases downfan from $\sim 70$ to $\sim 30 \mathrm{~m}$, and its depth varies between $\sim 20 \mathrm{~m}$ near the fan apex and $\sim 10 \mathrm{~m}$ near the fan toe. The channel has conveyed all of the historically recorded debris flows from the Illgraben catchment and is currently fixed in place by a series of concrete checkdams (Lichtenhahn, 1971; McArdell et al., 2007). The channel contains up to two generations of inset fill terraces below the present-day fan surface. A few distinct abandoned channels with widths of $\sim 10 \mathrm{~m}$ and depths of $\sim 4 \mathrm{~m}$ occur to the east of the active 
channel. Scattered large boulders on this part of the lobe are up to $3 \mathrm{~m}$ in diameter but are poorly organized. The boundary with lobe L8 is somewhat uncertain because of building construction and earthworks on this part of the fan. West of the present channel, there is a prominent abandoned channel with a width of 35-45 m and a maximum depth of $10 \mathrm{~m}$, lined by fragments of boulder levees. The dimensions and morphology of this paleochannel are comparable to those of the active channel, although its age and time of abandonment are not known. Debris-flow deposits on lobe L11 clearly downlap onto, and thus post-date, lobe L10.

\subsubsection{Rock avalanche deposit}

We estimated the minimum volume of the rock avalanche deposit as $\sim 6 \times 10^{6} \mathrm{~m}^{3}$. The surface of the rock avalanche deposit is noticeably rougher than that of the rest of the Illgraben fan at an $\sim 10$ $\mathrm{m}$ scale, owing to undulations of the deposit itself but also to the abundance of very large boulders with diameters of $\sim 10 \mathrm{~m}$ or more. The largest boulder measures $\sim 20 \mathrm{~m}$ along its longest axis. The boulders on the surface of the rock avalanche are mostly unorganized, with the exception of several radial, discontinuous linear ridges of 1-3 m width that extend north from the southern limit of the deposit (Fig. 2; e.g., Dufresne and Davies, 2009). In some places, these ridges are truncated by levees and channels of lobe L6. The western, southern, and eastern margins of the rock avalanche deposit appear to have been eroded after emplacement, apparently by debris flows, and are very steep (Fig. 3 and profile 5 in Fig. 4). The northern margin has a shallower surface slope and may be closer to the original depositional surface of the rock avalanche (profile 5 in Fig. 4). The internal fabric of the rock avalanche deposit is well exposed along its southern margin by an erosion scar of $\sim 30 \mathrm{~m}$ height. The clasts that comprise the deposit generally are more angular than those found in the active channel and on the fan surface. They consist mainly of white and sericitic quartzite (Gabus et al., 2008) and are embedded in a matrix of silty sand with gravel. The rock avalanche deposit shows a clear inverse grading over the height of the erosion scar, with the largest clasts forming a surface carapace. The lower parts of the exposure consist of finely crushed rock with a high degree of secondary cohesion, probably resulting from depositional processes. 
Cross-cutting relationships show that lobe L6 (and all later lobes) definitely post-dates emplacement of the rock avalanche, while L1 clearly pre-dates it. Lobes L2-L4 have no direct contact with the rock avalanche deposit, so it is impossible to establish their relative timing. Lobe L5, however, is confined between the rock avalanche and the wall of the Gorwetsch Grat. The contact between L5 and the rock avalanche is not well exposed, and it is therefore possible that the rock avalanche overlies (and thus post-dates) at least part of L5. This scenario is unlikely, however, because an earlier L5 would have likely overrun lobe L1 as well and would be visible to the east of its current confined position. We suggest instead that L5 post-dates the rock avalanche and that debris flows during L5 deposition were steered around the rock avalanche deposit toward the extreme western margin of the fan.

Emplacement of the rock avalanche appears to have had an important effect on the position of the fan apex. Projecting the trends of channel fragments toward the fan head reveals that most channels appear to radiate from an elongate patch of high intersection density, oriented NNW-SSE (Fig. 5). While the intersection density is highest, not surprisingly, at the present-day fan apex, a considerable number of channel trends, particularly those from lobes $L 2$ and $L 3$, intersect in an area $\sim 500 \mathrm{~m}$ farther south. This secondary area lies just south of and partly beneath the rock avalanche deposit (Fig. 5). We infer from this that older fan lobes may have been associated with a fan apex that was located about 500 m south of the present-day apex; if lobes L2 and L3 pre-date the rock avalanche, then this paleo-fan apex was altered and buried by emplacement of the rock avalanche.

\subsubsection{Fill in the Illgraben catchment}

Upstream of the rock avalanche, the channel is lined with discontinuous fragments of a fill terrace whose surface lies between 5 (upstream, near checkdam 1) and $20 \mathrm{~m}$ (downstream, near the catchment outlet) above the presently active channel (Fig. 3). A third-order polynomial interpolation from 42 elevations picked from these terrace fragments, and from lobe $\mathrm{L} 9$ on the fan surface, yields a continuous and quasi-planar sediment fill surface (Figs. 3 and 4), with a standard deviation of the residuals between known and interpolated elevations of $\sim 3 \mathrm{~m}$. This uncertainty is 
comparable to the expected variation in elevations on a debris-flow channel, as evidenced from the active channel bed and the rest of the Illgraben fan surface. This lower fill surface represents the minimum amount of sediment that was impounded within the Illgraben catchment at some point in the past. In contrast, the maximum amount of sediment that could be impounded within the catchment is set by the elevation of the rock avalanche deposit near the fan apex (Fig. 3). The elevation difference between the lower fill surface and the maximum elevation of the rock avalanche deposit (profile 5 in Fig. 4), at a similar distance from the fan apex, is $15 \mathrm{~m}$. Thus, to simulate the maximum possible elevation and geometry of sediment impounded behind the rock avalanche deposit, we shifted the lower fill surface upward by $15 \mathrm{~m}$ to establish an upper limiting fill surface shown in Figs. 3 and 4. This upper surface coincides with the top of a prominent fill terrace near Güetji (profiles 2 and 3 in Fig. 4). It also lies above the sampled and dated wood fragments embedded in boulder diamict between checkdams 1 and 10, interpreted here as matrixrich debris-flow deposits.

\subsection{Depositional chronology and exposure ages from cosmogenic nuclide and ${ }^{14} \mathrm{C}$ dating}

Of the 12 boulders sampled for ${ }^{10} \mathrm{Be}$, six did not yield enough pure quartz for successful dating. Exposure ages were determined for the remaining six quartzite boulders and for all four carbonate boulders (Tables 1, 2). Calculated exposure ages of these boulders range from $3220 \pm 250$ years (sample IG60) to $500 \pm 140$ years (sample IG18; Fig. 6; Tables 1, 2). The oldest dated surface on the Illgraben fan is the rock avalanche deposit (IG60), and we take this as a maximum age for emplacement of the rock avalanche (assuming no pre-avalanche exposure and inheritance). All other dated boulders show exposure ages that are at least 1600 years younger than the rock avalanche. Unfortunately, we were unable to find suitable boulders for exposure dating on lobes L3 and L4, and the samples taken from L1 and L2 did not yield enough quartz for reliable exposure dating, so we cannot test our inference from field relationships that lobe L1, and probably L2-L4, predated emplacement of the rock avalanche.

As noted above, L6 is the oldest lobe that clearly post-dates the rock avalanche. Exposure ages from lobes L6, L7, and L9 (samples IG19C, IG26C, IG29C, IG39, and IG39C) show that major 
resurfacing of the fan occurred by deposition of these lobes, and lobe L8, beginning around 1500 years ago. Taking into account the uncertainties on the exposure dates, the exposure ages are broadly consistent with the relative chronology of these surfaces, and we infer that deposition on lobe L6 occurred first, followed by activity on lobe L8 (undated but clearly younger than L9), L9, and then L7. Lobe L10 is the second youngest lobe in the relative and absolute chronology, with two samples (IG42 and IG43) yielding similar exposure ages of $690 \pm 160$ and $790 \pm 140$ years (Fig. 6; Table 1). Lobe L11, which includes the presently active channel, is the youngest lobe, and sample IG18 shows that depositional activity started there at least by $500 \pm 140$ years ago (Fig. 6).

The wood samples taken from sediment fill upstream of the rock avalanche (Fig. 3) yielded calibrated radiocarbon ages of 1948-1830 cal BP for S1, 1986-1876 cal BP for S2, and 1990-1893 cal BP for S3 (Table 4; Schlunegger et al., 2013). These ages are about 1200 years younger than the rock avalanche deposit and are consistent with deposition in sediments that were impounded by emplacement of the rock avalanche (the upper fill surface of Figs. 3 and 4).

\section{Discussion}

\subsection{Depositional chronology}

We have established the relative chronology of lobe activity on the Illgraben fan surface (Fig. 2) using cross-cutting relationships between different lobes, variations in surface morphology, and the geometric relationship of these lobes with the rock avalanche deposit. Cosmogenic nuclide exposure dating largely confirms this relative chronology and shows that deposits on the Illgraben fan surface are predominantly $<3200$ years old (Fig. 6). This resurfacing rate is rapid compared to, for example, well-dated debris-flow fan surfaces in the western USA (e.g., Dühnforth et al., 2007; d'Arcy et al., 2015), perhaps reflecting the higher rates of precipitation and sediment transfer in the Swiss Alps. The exposure ages do not necessarily reflect the true time span of depositional activity on the different lobes, however, as we cannot assume that we have sampled either the oldest or the youngest boulder on each lobe (Dühnforth et al., 2007). We note, also, that although the exposure ages are in approximate stratigraphic order, some ages overlap within uncertainty between different fan lobes. This overlap may reflect 'switching' of deposition back and forth 
between two adjacent lobes before final abandonment of the older lobe, or exposure of older material within a 'window' of younger deposits (as with lobes $L 4$ and $L 8$ ). Inheritance of ${ }^{10} \mathrm{Be}$ or ${ }^{36} \mathrm{Cl}$ in the sampled boulders, either from residence in the catchment or previous exposure and reworking on the fan, could also be responsible for large age ranges within individual lobes, and would lead to ages that are older than the true age of deposition. Neither inheritance mechanism can be conclusively ruled out, although we note that at present, sediment delivered to the main channel by small debris flows and rock fall in the upper Illgraben catchment (Fig. 1) is efficiently and rapidly evacuated to the fan by larger debris flows (Berger et al., 2010; Bennett et al., 2012, 2013). We therefore regard inheritance arising from long residence times of boulders in the catchment as likely to be minor, if present-day rates of catchment activity are indicative of past conditions. Abrasion of the boulders during transport in debris flows would also act to minimize the effects of inheritance because ${ }^{10} \mathrm{Be}$ accumulated near the rock surface would be preferentially removed (Carretier and Regard, 2011). Likewise, clear debris-flow depositional morphologies that are preserved on all lobes indicate that reworking and re-entrainment of older deposits is likely to be minimal, although it cannot be completely ruled out.

Only one sample from the rock avalanche (sample IG60) has been dated, making our interpretation of its emplacement age tenuous. Emplacement was likely to have occurred instantaneously (Ivy-Ochs et al., 2009; Stock and Uhrhammer, 2010), but on the other hand inherited ${ }^{10} \mathrm{Be}$ from previous exposure makes this a likely maximum age for the rock avalanche. This is because boulders that were exposed on the rock face prior to rock avalanche occurrence have been found to remain on top of the moving debris (Ivy-Ochs and Schaller, 2009; Ivy-Ochs et al., 2009; Stock and Uhrhammer, 2010). Only additional dates from different boulders from the surface of the rock avalanche deposit can overcome this uncertainty.

The samples from lobes $L 6, L 7, L 9, L 10$, and L11 are all substantially younger than the rock avalanche deposit near the fan apex. We infer that most of the present-day fan surface on the western half of the fan was deposited by debris flows after the rock avalanche deposit was emplaced. Apart from a single sample on lobe L9, the chronology of lobe deposition on the eastern 
half of the fan remains more uncertain. Centuries of agricultural land use and construction of stone walls, roads, houses, and irrigation ditches have destroyed important geomorphic evidence contained in relatively fragile landforms such as levees that may have local relief of as little as $1 \mathrm{~m}$. The low number of channel fragments mapped on the eastern half of the fan is a consequence of these effects (Fig. 5). Lobe L9 clearly downlaps onto, and thus post-dates, deposition of lobe L8, and sample IG19C suggests depositional activity on L9 until at least 1800 years after the rock avalanche. It is very likely that part or all of L8 is also younger than the rock avalanche, but we cannot rule out the possibility that some of this lobe pre-dates the rock avalanche or that L8 should in fact be split into several distinct lobes.

\subsection{Effects of the rock avalanche on fan morphology and sediment storage}

The emplacement of the rock avalanche near the fan apex left a distinct fingerprint on the morphology of the fan as a whole. The preservation of lobe L1 is a direct result of the rock avalanche, which isolated $L 1$ from the active fan surface and protected it from resurfacing during subsequent fan evolution.

The apex reconstruction (Fig. 5) shows that some channel fragments mapped on the fan, especially from older lobes like L2 and L3, are associated with a paleo-apex location 500 m south of the present-day apex, and thus those channels would be projected to run underneath the rock avalanche deposit. The simplest interpretation is that these channel fragments thus predate the rock avalanche. The apex location indicated by these channel fragments (Fig. 5) corresponds to the position of the mountain front to the east and west of the Illgraben catchment outlet, making it a logical geometry for the early fan; emplacement of the rock avalanche appears to have shifted the apex outboard into the Rhone Valley. Unfortunately, we could not use exposure dating to confirm the hypothesis that lobes L2 and L3 predate the rock avalanche owing to a lack of suitable sample material.

The rock avalanche deposit temporarily raised the local base level for the catchment and created additional upstream accommodation. The difference between the reconstructed upper bounding fill 
surface, which reaches the top of the rock avalanche deposit, and the present topography (Figs. 3 and 4) yields an approximate estimate of the potential accommodation generated by the rock avalanche of $\sim 3 \times 10^{6} \mathrm{~m}^{3}$ (about half of the estimated rock-avalanche volume). It is possible that this accommodation was at least partly filled by sediment accumulation in the catchment upstream of the rock avalanche and below the level of the upper bounding fill surface. In this model, sediment accumulation persisted at least locally for at least 1200 years after emplacement of the rock avalanche deposit, followed by breaching of the deposit, base-level fall in the catchment, and sediment evacuation. Breaching of the rock avalanche appears to have occurred first in a narrow corridor to the northwest of the presently active channel (pathway B1, Fig. 6), leading to deposition of lobe L5. This phase was followed by breaching in a northern direction (pathway B2, Fig. 6), incision through the deposit, and gradual removal of the sediment stored in the catchment, with incision extending at least upstream to checkdam 1. Our exposure dating results suggest that this incision was gradual, reaching a value of $\sim 15 \mathrm{~m}$ by $\sim 1500$ years ago using the oldest post-rock avalanche exposure ages (samples IG19C, IG26C and IG29C), and $~ 32 \mathrm{~m}$ by today (profile 5, Fig. 4). It is possible that sediment released by breaching of the rock avalanche has contributed to the widespread resurfacing of the fan that began about 1500 years ago, as the latter event is clearly younger than the ${ }^{14} \mathrm{C}$ ages obtained from the sediment fill. The observation that lobe L9 is coplanar with the lower fill surface in the catchment implies that fan aggradation led to backfilling well into the catchment, as observed on other debris-flow fans (e.g., Dühnforth et al., 2007).

This model of relatively rapid sediment storage and release is consistent with three independent pieces of evidence: the fact that the exposure age of the rock avalanche deposit $(3220 \pm 250$ years) is older than the radiocarbon ages from the sediment fill upstream ( 1900-2000 years); the fact that the radiocarbon ages are older than the exposure age of L9 (1400 \pm 100 years), and that L9 is coplanar with a lower fill surface in the catchment that is below the dated sediment fill; and the fact that the elevation of the toe of the Güetji terrace matches the upper bounding fill surface, implying substantial base-level fall. This interpretation is, however, not unique; we note in particular that there is limited evidence for thick sediment accumulation in the catchment above the lower fill surface, except for the section containing the wood samples and the toe of the Güetji terrace, and 
no preservation of any higher fill terrace surfaces within the catchment. An alternative explanation would be that post-rock avalanche aggradation in the catchment was limited to the lower fill terrace and that the Güetji terrace and dated sediment fill have recorded an unrelated episode of local deposition. Schlunegger et al. (2013) argued that the dated sediment fill was emplaced when sediment transport capacity in the Illgraben catchment was low in comparison to the hillslopederived sediment input and that subsequently the relative dominance between the two fluxes has changed. Schlunegger et al. (2013) attributed this change to a regional climatically driven trend in the relative importance of hillslope sediment supply and channel sediment evacuation that has been observed across the Alps during the Holocene (Norton et al., 2008). Our data do not allow us to discriminate between these alternative explanations for temporary sediment storage and release in the Illgraben catchment over the late Holocene. This case does, however, illustrate the potential for external events - in this case, emplacement of the rock avalanche - to affect the patterns of deposition on a fan surface, which could complicate efforts to correlate fan surface evolution with wider environmental drivers, such as short-term (100s to 1000 s of years) climate change.

\subsection{Shifts in the locus of deposition on the Illgraben fan}

The pattern of deposition on the Illgraben fan after emplacement of the rock avalanche deposit is consistent with repeated lateral and radial shifts in the locus of debris-flow deposition. The lateral shifts between lobes (e.g., L5 - L6 - L9 - L7 - L10 - L11) indicate that episodic avulsion has been an important process in fan development. Cross-cutting relationships between the lobes show that avulsions have been local and global (or fan-scale, between the western and eastern halves) and must have therefore involved avulsion nodes at a range of different radial positions from the fan apex to downstream. This is an important point because it illustrates that avulsions can occur at a variety of scales, and therefore probably by a variety of mechanisms, on a single fan. In terms of radial shifts in the depocenter, the presence of clear downlapping relationships between successive lobes (lobe L6 onto L2, L7 onto L3, L9 onto L8, and L10 onto L7) are consistent with backstepping of deposits toward the fan head. Following L9 deposition, the last episode of backstepping was followed by incision into the L9 surface and a basinward shift in deposition, allowing accumulation of lobes $L 10$ and L11. The post-rock avalanche deposits on the Illgraben fan 
are thus consistent with the model of avulsion, incision, and backstepping observed by de Haas et al. (2016) in fan experiments and documented for a number of fluvial fan and fan-delta settings (Nicholas and Quine, 2007; Clarke et al., 2010; Powell et al., 2012; Reitz and Jerolmack, 2012).

Our interpretation of the fan surface evolution over the past 3200 years is in disagreement with a dendrogeomorphic analysis of growth disturbances by debris flows in Stoffel et al. (2008b). Those authors attributed growth disturbances to debris flows impacting trees in the vicinity of sample IG60 for several years in the nineteenth and twentieth centuries and as late as 1957 . This would have required at least a temporary channel bed elevation at profile 5 (Fig. 4) of almost $838 \mathrm{~m}$ asl, or $>15 \mathrm{~m}$ higher than the surface of lobe $\mathrm{L} 9$ and $>32 \mathrm{~m}$ above the local channel bed, followed by widespread and rapid incision over an area of several tens of thousands of square meters. However, such significant change of the channel bed in this area in such a short time is not seen in either the relevant topographic maps of the area between 1845 and 1933 (Dufour, 1845; Siegfried, 1886, 1907, 1915, 1924, and 1933) nor from the 1:25,000 topographic map from 1966 (sheet 1287 Sierre) and is also in disagreement with our exposure dating of lobe L9 (IG19C, $1400 \pm 100$ years).

In summary, the changes in the spatial pattern of debris-flow deposition on the Illgraben fan surface, constrained by relative and by absolute dating, can be explained by episodic channel avulsion, fan-head incision, and backstepping of debris-flow deposits toward the fan apex. This basic pattern is complicated by emplacement of a large rock avalanche deposit about 3200 years ago. This study yields the first quantitative evidence for these variations in the spatial patterns of debris-flow deposition on $\sim 10^{3}$ y time scales in the Alps and provides valuable field-scale evidence for comparison to the results of analogue or numerical simulations of debris-flow fan evolution. Our results also illustrate the complexity of fan systems in an active and dynamic erosional environment such as the Alps.

\section{Conclusions}

Quantitative reconstructions of debris-flow fan evolution in active alpine settings are important for understanding past flow occurrence and future flow hazard but remain relatively rare. In this paper, 
we have reconstructed fan evolution and sediment storage in the Illgraben sediment routing system since $\sim 3200$ years ago. This reconstruction includes a detailed chronology of lobe deposition on the debris-flow fan by means of cosmogenic exposure dating of ten quartzite and carbonate boulders. The fan shows evidence for lateral and for radial shifts in the locus of debrisflow deposition, consistent with a conceptual model of fan surface evolution by channel avulsion, fan-head incision, and backstepping toward the fan apex. The pattern is complicated by the emplacement of a rock avalanche deposit of at least $6 \times 10^{6} \mathrm{~m}^{3}$ volume near the fan apex and dated by a single ${ }^{10} \mathrm{Be}$ sample to $3220 \pm 250$ years. Emplacement of the rock avalanche may have led to the upstream trapping of sediment within the Illgraben catchment and appears to have shifted the fan apex by about $500 \mathrm{~m}$ to the north into the Rhone Valley. In this model, eventual breaching of the rock avalanche allowed incision and evacuation of much, but not all, of the stored sediment within the catchment and may have contributed to widespread resurfacing of the fan that began about 1500 years ago. Debris-flow activity during the last $~ 500$ years was concentrated on lobe L11 and, since at least A.D. 1793, has been concentrated in or near the present-day channel. Our results illustrate the complexity of fan evolution in alpine settings, where sediment may be delivered to fans by a range of different processes and where direct correlation between fan lobe development and short-term (100s to 1000 s of years) climate change may be complicated by local controls on sediment availability.

\section{Acknowledgements}

The land owners, Burgschaft Leuk (Stefan Eggo) and Paul Passeraub (Turtmann), are acknowledged for giving permission for sampling boulders. DTM-AV data were provided by Swisstopo. Cosmogenic nuclide sample preparation and AMS measurements were supported by the Laboratory of Ion Beam Physics, ETH Zurich. We thank P.W. Kubik for ${ }^{10}$ Be AMS measurements. Preparation of wood samples and dating by the radiocarbon lab of the Physical Institute of the University of Bern was funded by the Swiss National Science Foundation (20T021120464). Fieldwork was funded by NERC grant NE/G009104/1 and by a Royal Geographical Society fieldwork grant, and Peter Schürch was funded by a Durham University Doctoral Fellowship. We thank Mitch d'Arcy, two anonymous reviewers, and the editor, Richard Marston, for 
constructive reviews that helped to improve and focus the manuscript.

\section{References}

Alfimov, V., Ivy-Ochs, S., 2009. How well do we understand production of ${ }^{36} \mathrm{Cl}$ in limestone and dolomite? Quaternary Geochronology 4, 462-474.

Arattano, M., Giordan, D., Luino, F., Conte, R., Lazzari, A., Franzi, L., 2010. Risk management on an alluvial fan: A case study of the 2008 debris- flow event at Villar Pellice (Piedmont, N-W Italy). Natural Hazards and Earth System Science 10, 999-1008.

Arbellay, E., Stoffel, M., Bollschweiler, M., 2010. Dendrogeomorphic reconstruction of past debrisflow activity using injured broad-leaved trees. Earth Surface Processes and Landforms 35, 399-406.

Badoux, A., Graf, C., Rhyner, J., Kuntner, R., McArdell, B. W., 2008. A debris-flow alarm system for the alpine Illgraben catchment: design and performance. Natural Hazards 49, 517-539.

Balco, G., Stone, J.O., Lifton, N.A., Dunai, T.J., 2008. A complete and easily accessible means of calculating surface exposure ages or erosion rates from ${ }^{10} \mathrm{Be}$ and ${ }^{26} \mathrm{Al}$ measurements. Quaternary Geochronology 3, 174-95.

Balco, G., Briner, J., Finkel, R.C., Rayburn, J.A., Ridge, J.C., Schaefer, J.M., 2009. Regional Beryllium-10 production rate calibration for late-glacial northeastern North America. Quaternary Geochronology 4, 93-107.

Bardou, E., Fournier, F., Sartori, M., 2003. Paleoflood reconstruction at Illgraben torrent (Switzerland): a current need for event frequency estimation. In: Thorndycraft, V., Benito, G., BArriendos, M., Llasat, C. (Eds.), Palaeofloods, Historical Data \& Climatic Variability: Applications in Flood Risk Assessment. Proceedings of the International PHE- FRA Workshop. Centro de Ciencias Medioambientales, Barcelona, Spain, pp. 53-59.

Bennett, G., Molnar, P., Eisenbeiss, H., McArdell, B.W., 2012. Erosional power in the Swiss Alps: characterization of slope failure in the Illgraben, Earth Surface Processes and Landforms 37, 1627-1640, doi:10.1002/esp.3263. 
Bennett, G.L., Molnar, P., McArdell, B.W., Schlunegger, F., Burlando, P., 2013. Patterns and controls of sediment production, transfer, and yield in the Illgraben. Geomorphology 188, 6882.

Bennett, G.L., Molnar, P., McArdell, B.W., Burlando, P., 2014. A probabilistic sediment cascade model of sediment transfer in the Illgraben. Water Resources Research 50, doi:10.1002/2013WR013806.

Berger, C., McArdell, B. W., Schlunegger, F., 2010. Sediment transfer patterns at the Illgraben catchment, Switzerland: Implications for the time scales of debris flow activities. Geomorphology 125, 421-432.

Berger, C., McArdell, B.W., Schlunegger, F., 2011. Direct measurement of channel erosion by debris flows, Illgraben, Switzerland. Journal of Geophysical Research - Earth Surface 116, F01002, doi:10.1029/2010JF001722.

Blair, T.C., McPherson, J.G., 1994. Alluvial fans and their natural distinction from river based on morphology, hydraulic processes, sedimentary processes, and facies assemblages. Journal of Sedimentary Research 64, 450-489.

Bollschweiler, M., Stoffel, M., 2010. Tree rings and debris flows: recent development, future directions. Progress in Physical Geography 34, 625-645.

Bronk Ramsey, C., 2009. Bayesian analysis of radiocarbon dates. Radiocarbon 51, 337-360.

Burtin, A., Hovius, N., McArdell, B.W., Turowski, J.M., Vergne, J., 2014. Seismic constraints on dynamic links between geomorphic processes and routing of sediment in a steep mountain catchment. Earth-Surface Dynamics 2, 21-33.

Carretier, S., Regard, V., 2011. Is it possible to quantify pebble abrasion and velocity in rivers using terrestrial cosmogenic nuclides? Journal of Geophysical Research - Earth Surface 116, F04003, doi:10.1029/2011JF001968.

Christl, M., Vockenhuber, C., Kubik, P.W., Wacker, L., Lachner, J., Alfimov, V., Synal, H.A., 2013. The ETH Zürich AMS facilities: Performance parameters and reference materials. Nuclear Instruments and Methods in Physics Research Section B: Beam Interactions with Materials and Atoms 294, 29-38.

Clarke, L., Quine, T.A., Nicholas, A., 2010. An experimental investigation of autogenic behaviour 
during alluvial fan evolution. Geomorphology 115, 278-285.

D’Arcy, M., Roda Boluda, D.C., Whittaker, A.C., Carpineti, A., 2015. Dating alluvial fan surfaces in Owens Valley, California, using weathering fractures in boulders. Earth Surface Processes and Landforms 40, 487-501.

Davies, T.R.H., Korup, O., 2007. Persistent alluvial fanhead trenching resulting from large, infrequent sediment inputs. Earth Surface Processes and Landforms 32, 725-742.

de Haas, T., Braat, L., Leuven, J.R.F.W., Lokhorst, I.R., Kleinhans, M.G., 2015a. Effects of debrisflow composition on runout, depositional mechanisms and deposit morphology in laboratory experiments. Journal of Geophysical Research - Earth Surface 120, doi:10.1002/2015JF003525.

de Haas, T., Kleinhans, M.G., Carbonneau, P.E., Rubensdotter, L., Hauber, E., 2015b. Surface morphology of fans in the high-Arctic periglacial environment of Svalbard: controls and processes. Earth-Science Reviews 146, 163-182.

de Haas, T., van den Berg, W., Braat, I., Kleinhans, M.G., 2016. Autogenic avulsion, channelisation, and backfilling dynamics of debris-flow fans. Sedimentology doi:10.1111.sed12275.

de Scally, F.A., Owens, L.F., Louis, J., 2010. Controls on fan depositional processes in the schist ranges of the Southern Alps, New Zealand, and implications for debris-flow hazard assessment. Geomorphology 122, 99-116.

Dühnforth, M., Densmore, A.L., Ivy-Ochs, S., Allen, P.A., Kubik, P.W., 2007. Timing and patterns of debris flow deposition on Shepherd and Symmes creek fans, Owens Valley, California, deduced from cosmogenic ${ }^{10} \mathrm{Be}$. Journal of Geophysical Research - Earth Surface 112, F03S15, doi:10.1029/2006JF000562

Dühnforth, M., Densmore, A.L., Ivy-Ochs, S., Allen, P.A., 2008. Controls on sediment evacuation from glacially modified and unmodified catchments in the eastern Sierra Nevada, California. Earth Surface Processes and Landforms 33, 1602-1613.

Dufour, G.-H., 1845. Topographische Karte der Schweiz (Dufourkarte), sheet XVII. Swisstopo, Bundesamt für Landestopographie, Wabern, http://map.geo.admin.ch/, accessed 7 July 2011. Dufresne, A., Davies, T., 2009. Longitudinal ridges in mass movement deposits. Geomorphology 
$105,171-181$.

Dunne, J., Elmore, D., Muzikar, P., 1999. Scaling factors for the rates of production of cosmogenic nuclides for geometric shielding and attenuation at depth on sloped surfaces. Geomorphology 27, 3-11.

Franke, D., Hornung, J., Hinderer, M., 2014. A combined study of radar facies, lithofacies and three-dimensional architecture of an alpine alluvial fan (Illgraben fan, Switzerland). Sedimentology doi:10.1111/sed.12139.

Frankel, K.L., Dolan, J.F., 2007. Characterizing arid region alluvial fan surface roughness with airborne laser swath mapping digital topographic data. Journal of Geophysical Research Earth Surface 112, F02025, doi:10.1029/2006JF000644.

Gabus, J., Weidmann, M., Sartori, M., Burri, M., 2008. Feuille 1287 Sierre. - Atlas gèol. Suisse 1:25 000, No. 111. Office Federal de Topographie, Wabern.

Harvey, A.M., 2011. Dryland alluvial fans. In: Thomas, D.S.G. (Ed.), Arid Zone Geomorphology: Process, Form and Change in Drylands, Third Edition. John Wiley, Chichester, pp. 333-371. Helsen, M.M., Koop, P.J.M., van Steijn, H., 2002. Magnitude-frequency relationship for debris flows on the fan of the Chalence torrent, Valgaudemar (French Alps). Earth Surface Processes and Landforms 27, 1299-1307.

Hornung, J., Pflanz, D., Hechler, A., Beer, A., Hinderer, M., Maisch, M., Bieg, U., 2010. 3-D architecture, depositional patterns and climate triggered seidment fluxes of an alpine alluvial fan (Samedan, Switzerland). Geomorphology 115, 202-214.

Hubert, J.F., Filipov, A.J., 1989. Debris-flow deposits in alluvial fans on the west flank of the White Mountains, Owens Valley, California, U.S.A. Sedimentary Geology 61, 177-205.

Hürlimann, N., Rickenmann, D., Graf, C., 2003. Field and monitoring data of debris flow events in the Swiss Alps. Canadian Geotechnical Journal 40, 161-175.

Ivy-Ochs, S., Kober, F., 2008. Surface exposure dating with cosmogenic nuclides.

Eiszeitalter und Gegenwart 57, 179-209.

Ivy-Ochs, S., Schaller, M., 2009. Examining processes and rates of landscape change with cosmogenic radionuclides. In: Froehlich, K. (Ed.), Environmental Radionuclides: Tracers and Timers of Terrestrial Processes. Radioactivity in the Environment Vol. 16. Elsevier, 
Amsterdam, pp. 231-294.

Ivy-Ochs, S., Synal, H.-A., Roth, C., Schaller, M., 2004. Initial results from isotope dilution for Cl and $36 \mathrm{CI}$ measurements at the PSI/ETH Zurich AMS facility. Nuclear Instruments and Methods in Physics Research, Section B: Beam Interactions with Materials and Atoms 223$224,623-627$.

Ivy-Ochs, S., Kerschner, H., Reuther, A., Preusser, F., Heine, K., Maisch, M., Kubik, P.W., Schluchter, C., 2008. Chronology of the last glacial cycle in the European Alps. Journal of Quaternary Science 23, 559-573.

Ivy-Ochs, S., Maisch, M., Poschinger, A., Synal, H., 2009. Surface exposure dating of the Flims landslide, Graubünden, Switzerland. Geomorphology 103, 104-112.

Kim, B.C., Lowe, D.R., 2004. Depositional processes of the gravelly debris flow deposits, South Dolomite alluvial fan, Owens Valley, California. Geoscience Journal - Seoul 8, 153-170.

Kim, W., Muto, T., 2007. Autogenic response of alluvial-bedrock transition to base-level variation: experiment and theory. Journal of Geophysical Research - Earth Surface 112, F03S14, doi:10.1029/2006JF000561.

Korup, O., Densmore, A., Schlunegger, F., 2010. The role of landslides in mountain range evolution. Geomorphology 120, 77-90.

Lichtenhahn, C., 1971. Zwei Betonmauern: die Geschieberückhaltesperre am Illgraben (Wallis). In: F.f.v. Hochwasserbekämpfung Vol. 3. Villach, Kärnten, Austria, pp. 451-456.

Marchand, A., 1871. Les torrents des Alpes. Revue des Eaux et Forêts 10, 77-95.

McArdell, B.W., Bartelt, P., Kowalski, J., 2007. Field observations of basal fluid pore pressure in a debris flow. Geophysical Research Letters 34, L074606, doi:10.1029/2006GL029183.

McDonald, E., McFadden, L.D., Wells, S.G., 2003. Regional response of alluvial fans to the Pleistocene-Holocene climatic transition, Mojave Desert, California. In: Enzel, Y., Wells, S.G., Lancaster, N. (Eds.), Paleoenvironments and Paleohydrology of the Mojave and Southern Great Basin Deserts. Geological Society of America Special Paper 368, pp. 189205.

Nicholas, A.P., Quine, T.A., 2007. Modelling alluvial landform change in the absence of external environmental forcing. Geology 35, 527-530. 
Nishiizumi, K., Imamura, M., Caffee, M., Southon, J., Finkel, R., McAninch, J., 2007. Absolute calibration of ${ }^{10} \mathrm{Be}$ AMS standards. Nuclear Instruments and Methods in Physics Research, Section B: Beam Interactions with Materials and Atoms 258, 403-413.

Norton, K., von Blanckenburg, F., Schlunegger, F., Schwab, M., Kubik, P., 2008. Cosmogenic nuclide-based investigation of spatial erosion and hillslope channel coupling in the transient foreland of the Swiss Alps. Geomorphology 95, 474-486.

Powell, E.J., Kim, W., Muto, T., 2012. Varying discharge controls on timescales of autogenic storage and release processes in fluvio-deltaic environments: tank experiments. Journal of Geophysical Research - Earth Surface 117, F02011, doi:10.1029/2011JF002097.

Reimer, P.J., Bard, E., Bayliss, A., Beck, J.W., Blackwell, P.G., Ramsey, C.B., Buck, C.E., Cheng, H., Edwards, R.L., Friedrich, M., Grootes, P.M., 2013. IntCal13 and Marine13 radiocarbon age calibration curves 0-50,000 years cal BP. Radiocarbon 55, 1869-87.

Reitz, M.D., Jerolmack, D.J., 2012. Experimental alluvial fan evolution: channel dynamics, slope controls, and shoreline growth. Journal of Geophysical Research - Earth Surface 117, F02021, doi:10.1029/2011JF002261.

Rickenmann, D., Hürlimann, M., Graf, C., Näf, D., Weber, D., 2001. MurgangBeobachtungsstationen in der Schweiz. Wasser Energie Luft 93, 1-8.

Savi, S., Norton, K.P., Picotti, V., Akçar, N., Delunel, R., Brardinoni, F., Kubik, P., Schlunegger, F., 2014. Quantifying sediment supply at the end of the last glaciation: dynamic reconstruction of an alpine debris-flow fan. Geological Society of America Bulletin 126, 773-790.

Schlunegger, F., Badoux, A., McArdell, B.W., Gwerder, C., Schnydrig, D., Rieke-Zapp, D., Molnar, P., 2009. Limits of sediment transfer in an alpine debris-flow catchment, Illgraben, Switzerland. Quaternary Science Reviews 28, 1097-1105.

Schlunegger, F., Norton, K., Caduff, R., 2013. Hillslope processes in temperate environments. In: Shroder, J., Marston, R., and Stoffel, M. (Eds.), Treatise on Geomorphology, Vol. 7. Academic Press, San Diego, pp. 337-354.

Schürch, P., Densmore, A.L., Rosser, N.J., McArdell, B.W., 2011. Dynamic controls on erosion and deposition on debris-flow fans. Geology 39, 827-830. 
Schumm, S., Mosley, M., Weaver, W., 1987. Experimental Fluvial Geomorphology. John Wiley and Sons, New York.

Siegfried, H., 1886, 1907, 1915, 1924 and 1933. Topographischer Atlas der Schweiz

(Siefgriedkarte), sheet 482, digital edition. Swisstopo, Bundesamt für Landestopographie, Wabern, digital edition published 2003.

Staley, D.M., Wasklewicz, T.A., Blaszczynski, J.S., 2006. Surficial patterns of debris flow deposition on alluvial fans in Death Valley, California, using airborne laser swath mapping data. Geomorphology 74, 152-163.

Stock, G., Uhrhammer, R., 2010. Catastrophic rock avalanche 3600 years BP from El Capitan, Yosemite Valley, California. Earth Surface Processes and Landforms 35, 941-951.

Stoffel, M., 2010. Magnitude-frequency relationships of debris flows - a case study based on field surveys and tree-ring records. Geomorphology 116, 67-76.

Stoffel, M., Lièvre, I., Conus, D., Grichting, M.A., Raetzo, H., Gaertner, H.W., Monbaron, M., 2005. 400 years of debris-flow activity and triggering weather conditions: Ritigraben, Valais, Switzerland. Arctic, Antarctic, and Alpine Research 37, 387-395.

Stoffel, M., Conus, D., Grichting, M.A., Lièvre, I., Maître, G., 2008a. Unravelling the pattern of late Holocene debris-flow activity on a cone in the Swiss Alps: chronology, environment and implications for the future. Global and Planetary Change 60, 222-234.

Stoffel, M., Bollschweiler, M., Leutwiler, A., Aeby, P., 2008b. Tree-ring reconstruction of debris-flow events leading to overbank sedimentation on the Illgraben cone (Valais Alps, Switzerland). The Open Geology Journal 2, 18-29.

Stoffel, M., Tiranti, D., Huggel, C., 2014. Climate change impacts on mass movements - case studies from the European Alps. Science of the Total Environment 493, 1255-1266.

Stone, J., Allan, G., Fifield, L., Cresswell, R., 1996. Cosmogenic chlorine-36 from calcium spallation. Geochimica et Cosmochimica Acta 60, 679-692.

Stone, J., Evans, J., Fifield, L., Allan, G., Cresswell, R., 1998. Cosmogenic chlorine-36 production in calcite by muons. Geochimica et Cosmochimica Acta 62, 433-454.

Straub, K.M., Paola, C., Mohrig, D., Wolinsky, M.A., George, T., 2009. Compensational stacking of channelized sedimentary deposits. Journal of Sedimentary Research 79, 673-688. 
Suwa, H., Okuda, S., 1983. Deposition of debris flows on a fan surface, Mt. Yakedake, Japan. Zeitschrift für Geomorphologie N.F., Supplementband 46, 79-101.

van Dijk, W.M., Postma, G., Kleinhans, M.G., 2009. Autocyclic behavior of fan deltas: an analogue experimental study. Sedimentology 56, 1569-1589.

van Dijk, W.M., Kleinhans, M.G., Postma, G., Kraal, E., 2012. Contrasting morphodynamics in alluvial fans and fan deltas: effect of the downstream boundary. Sedimentology 59, 21252145.

Ventra, D., Nichols, G.J., 2014. Autogenic dynamics of alluvial fans in endorheic basins: outcrop examples and stratigraphic significance. Sedimentology 61, 767-791.

Whipple, K.X., Dunne, T., 1992. The influence of debris-flow rheology on fan morphology, Owens Valley, California. Geological Society of America Bulletin 104, 887-900. 
Table 1

Details of ${ }^{10} \mathrm{Be}$ samples and AMS results

\begin{tabular}{|c|c|c|c|c|c|c|c|}
\hline Sample & Fan lobe & $\begin{array}{l}\text { Latitude } \\
\left({ }^{\circ} \mathrm{N}\right)\end{array}$ & $\begin{array}{l}\text { Longitude } \\
\left({ }^{\circ} \mathrm{E}\right)\end{array}$ & $\begin{array}{l}\text { Elevation } \\
(\mathrm{m})\end{array}$ & $\begin{array}{l}\text { Shield. } \\
\text { corr. }\end{array}$ & $\begin{array}{l}{ }^{10} \mathrm{Be} \text { conc. } \\
\left(\text { atoms g }{ }^{-1}\right)\end{array}$ & $\begin{array}{l}{ }^{10} \mathrm{Be} \text { age } \\
(y \pm 1 \sigma)\end{array}$ \\
\hline IG60 & $\begin{array}{l}\text { Rock } \\
\text { avalanche }\end{array}$ & 46.2946 & 7.6324 & 824 & 0.974 & $24800 \pm 1540$ & $3220 \pm 250$ \\
\hline IG39 & $\mathrm{L} 7$ & 46.3010 & 7.6242 & 691 & 0.982 & $7100 \pm 110$ & $1040 \pm 170$ \\
\hline IG42 & L10 & 46.2997 & 7.6316 & 740 & 0.979 & $4900 \pm 110$ & $690 \pm 160$ \\
\hline IG43 & L10 & 46.2974 & 7.6324 & 767 & 0.980 & $5730 \pm 950$ & $790 \pm 140$ \\
\hline IG18 & L11 & 46.3014 & 7.6318 & 727 & 0.975 & $3460 \pm 960$ & $500 \pm 140$ \\
\hline
\end{tabular}


Table 2

Details of ${ }^{36} \mathrm{Cl}$ samples and AMS results

\begin{tabular}{lllllllll}
\hline Sample & Fan lobe & $\begin{array}{l}\text { Latitude } \\
\left({ }^{\circ} \mathbf{N}\right)\end{array}$ & $\begin{array}{l}\text { Long. } \\
\left({ }^{\circ} \mathbf{E}\right)\end{array}$ & $\begin{array}{l}\text { Elev. } \\
(\mathbf{m})\end{array}$ & $\begin{array}{l}\text { Shield. } \\
\text { corr. }\end{array}$ & $\begin{array}{l}\mathbf{C l} \\
(\mathbf{p p m})\end{array}$ & $\begin{array}{l}{ }^{36} \mathbf{C l ~ c o n c . ~} \\
\left(\text { atoms } \mathbf{~}^{-1}\right)\end{array}$ & $\begin{array}{l}{ }^{36} \mathbf{C l} \text { age } \\
(\mathbf{y} \pm \mathbf{1 \sigma})\end{array}$ \\
\hline IG26C & L6 & 46.2994 & 7.6229 & 694 & 0.966 & $36.2 \pm 0.6$ & $59600 \pm 3300$ & $1560 \pm 100$ \\
IG29C & L6 & 46.2980 & 7.6211 & 689 & 0.961 & $43.7 \pm 0.3$ & $57700 \pm 3300$ & $1590 \pm 120$ \\
IG39C & L7 & 46.3015 & 7.6243 & 690 & 0.982 & $12.7 \pm 0.2$ & $52310 \pm 4030$ & $1350 \pm 120$ \\
IG19C & L9 & 46.2980 & 7.6416 & 739 & 0.983 & $8.4 \pm 0.3$ & $52310 \pm 3260$ & $1400 \pm 100$ \\
\hline
\end{tabular}


Table 3

Major and trace element concentrations for samples dated with ${ }^{36} \mathrm{Cl}$

\begin{tabular}{llllllllllll}
\hline Sample & $\begin{array}{l}\mathrm{Al}_{2} \mathbf{O}_{3} \\
(\%)\end{array}$ & $\begin{array}{l}\mathrm{CaO} \\
(\%)\end{array}$ & $\begin{array}{l}\mathrm{Fe}_{2} \mathbf{O}_{3} \\
(\%)\end{array}$ & $\begin{array}{l}\mathrm{K}_{2} \mathbf{O} \\
(\%)\end{array}$ & $\begin{array}{l}\mathbf{M g O} \\
(\%)\end{array}$ & $\begin{array}{l}\mathrm{SiO}_{2} \\
(\%)\end{array}$ & $\begin{array}{l}\mathrm{TiO}_{2} \\
(\%)\end{array}$ & $\begin{array}{l}\mathbf{B} \\
(\mathbf{p p m})\end{array}$ & $\begin{array}{l}\mathbf{S m} \\
(\mathbf{p p m})\end{array}$ & $\begin{array}{l}\mathrm{Th} \\
(\mathbf{p p m})\end{array}$ & $\begin{array}{l}\mathbf{U} \\
(\mathbf{p p m})\end{array}$ \\
\hline IG26C & 2.65 & 47.7 & 0.84 & 1.24 & 1.20 & 7.62 & 0.09 & 33 & 1.4 & 1.6 & 0.93 \\
IG29C & 5.11 & 38.8 & 1.47 & 2.40 & 2.43 & 13.3 & 0.21 & n.a. & 1.5 & 3.6 & 1.75 \\
IG39C & 0.48 & 55.7 & 0.22 & 0.12 & 0.34 & 1.10 & 0.02 & n.a. & 0.2 & 0.4 & 3.22 \\
IG19C & 0.24 & 53.3 & 0.19 & 0.05 & 0.47 & 0.91 & 0 & n.a. & 0.1 & 0.2 & 1.20 \\
\hline
\end{tabular}

$\mathrm{Cr}_{2} \mathrm{O}_{3}, \mathrm{MnO}, \mathrm{Na}_{2} \mathrm{O}, \mathrm{P}_{2} \mathrm{O}_{5}$, Gd below detection limit; n.a., not analyzed. 
Table 4

Details of ${ }^{14} \mathrm{C}$ samples and AMS results

\begin{tabular}{lllllll}
\hline Sample & $\begin{array}{l}\text { Laboratory } \\
\text { number }\end{array}$ & $\begin{array}{l}\text { Height above } \\
\text { channel bed }(\mathbf{m})\end{array}$ & $\mathbf{D}^{\mathbf{1 4}} \mathbf{C}(\%)$ & $\boldsymbol{\delta}^{13} \mathbf{C}(\%)$ & $\begin{array}{l}\text { Conv. radiocarbon age } \\
(\mathbf{y ~ B P} \pm \mathbf{1 \sigma})\end{array}$ & $\begin{array}{l}\text { Calibrated age } \\
\text { (cal BP) }\end{array}$ \\
\hline S1 & B-9629 & 8.0 & $-215.9 \pm 2.2$ & $-23.6 \pm 0.2$ & $1950 \pm 20$ & $1948-1830$ \\
S2 & B-9630 & 8.0 & $-217.8 \pm 2.3$ & $-23.8 \pm 0.2$ & $1970 \pm 20$ & $1986-1876$ \\
S3 & B-9631 & 12.2 & $-219.3 \pm 2.2$ & $-24.9 \pm 0.2$ & $1990 \pm 20$ & $1990-1893$ \\
\hline
\end{tabular}




\section{Figures}

Fig. 1. Overview of Illgraben catchment and fan system. Inset shows Illgraben location in southwestern Switzerland. Background hillshade image is derived from Swisstopo DTM-AV digital elevation model, with 2-m cell size. Extent of rock avalanche deposits in the Illgraben catchment (emplaced in 1961) and at the head of the Illgraben fan (analyzed here) are shown in the crosshatched pattern. Colors indicate extents of marble/dolomite and quartzite within the catchment, separated by an inactive fault; geology is simplified from Gabus et al. (2008). Selected checkdams, and their numbers, are shown by short black lines. Box shows location of Fig. 3.

Fig. 2. Depositional lobes on the Illgraben fan, as determined by field mapping cross-checked against the DTM-AV DEM. Lobes are numbered in order of decreasing age, from L1 (oldest) to L11 (presently active). RA, rock avalanche deposit near fan apex. Note the linear ridges trending northsouth on the surface of the rock avalanche. Star shows the lower elevation limit of the rock avalanche deposit at $748 \mathrm{~m}$ asl, used for volume reconstruction. Cleared and levelled fields and buildings in the town of Susten are visible in the upper-right corner.

Fig. 3. Relationships between sediment fill and rock avalanche deposit near the Illgraben fan apex. Rock avalanche deposit is shown in the cross-hatched pattern. The lower fill surface was interpolated from spot elevations on fill terraces and the coplanar lobe L9 on the Illgraben fan. The upper fill surface was constructed by shifting the lower fill surface upward by $15 \mathrm{~m}$ to intersect the top of the rock avalanche deposit. Shaded areas show the intersection of topography with each fill surface, with a range of $\pm 3 \mathrm{~m}$ of elevation uncertainty. White squares show locations of radiocarbon samples S1-S3 from within fill on the right bank of the Illgraben channel. Dashed black line shows the downstream limit of fill terraces within the Illgraben catchment, taken as the downstream fill limit for calculation of sediment volumes. Solid black lines show the locations of profiles in Fig. 4. 
Fig. 4. Topographic profiles across the Illgraben channel. See Fig. 3 for locations. Profiles are oriented looking downstream (north to left) and are ordered from upstream (top) to downstream (bottom). Dashed lines show the elevation of the upper and lower fill surfaces at the position of each profile. White squares in profile 1 show the locations of radiocarbon samples S1-S3. The top of a prominent fill terrace at Güetji is shown in profiles 2 and 3. Profile 5 shows the topography of the rock avalanche deposit (RA), along with the upward shift of $15 \mathrm{~m}$ used to generate the upper surface from the lower surface.

Fig. 5. Fan apex reconstruction. Red lines show fragments of channels that were projected back toward the fan head to reconstruct the most likely apex position through time. Colors show the number of intersections between projected channel fragments; higher intersection numbers should correspond to likely fan apex positions. The highest intersection density is found just downstream of the rock avalanche deposit (RA), where lobes L6-L10 diverge toward the western sector of the fan. High intersection densities are also found to the south of this point, however, especially associated with channel fragments from lobes $L 2$ and $L 3$. This is consistent with a northward shift of $\sim 500 \mathrm{~m}$ in the fan apex, perhaps associated with emplacement of the RA.

Fig. 6. ${ }^{10} \mathrm{Be}$ and ${ }^{36} \mathrm{Cl}$ cosmogenic ages from the Illgraben fan. Lobes as in Fig. 2. Ages are given with $\pm 1 \sigma$ uncertainties. See Tables 1 and 2 for analytical details. Upper-right panel shows ages ordered by depositional setting and relative lobe age and also shows the radiocarbon ages from fill terrace samples in the catchment. B1 and B2 (white arrows) show alternative depositional pathways onto the fan. 


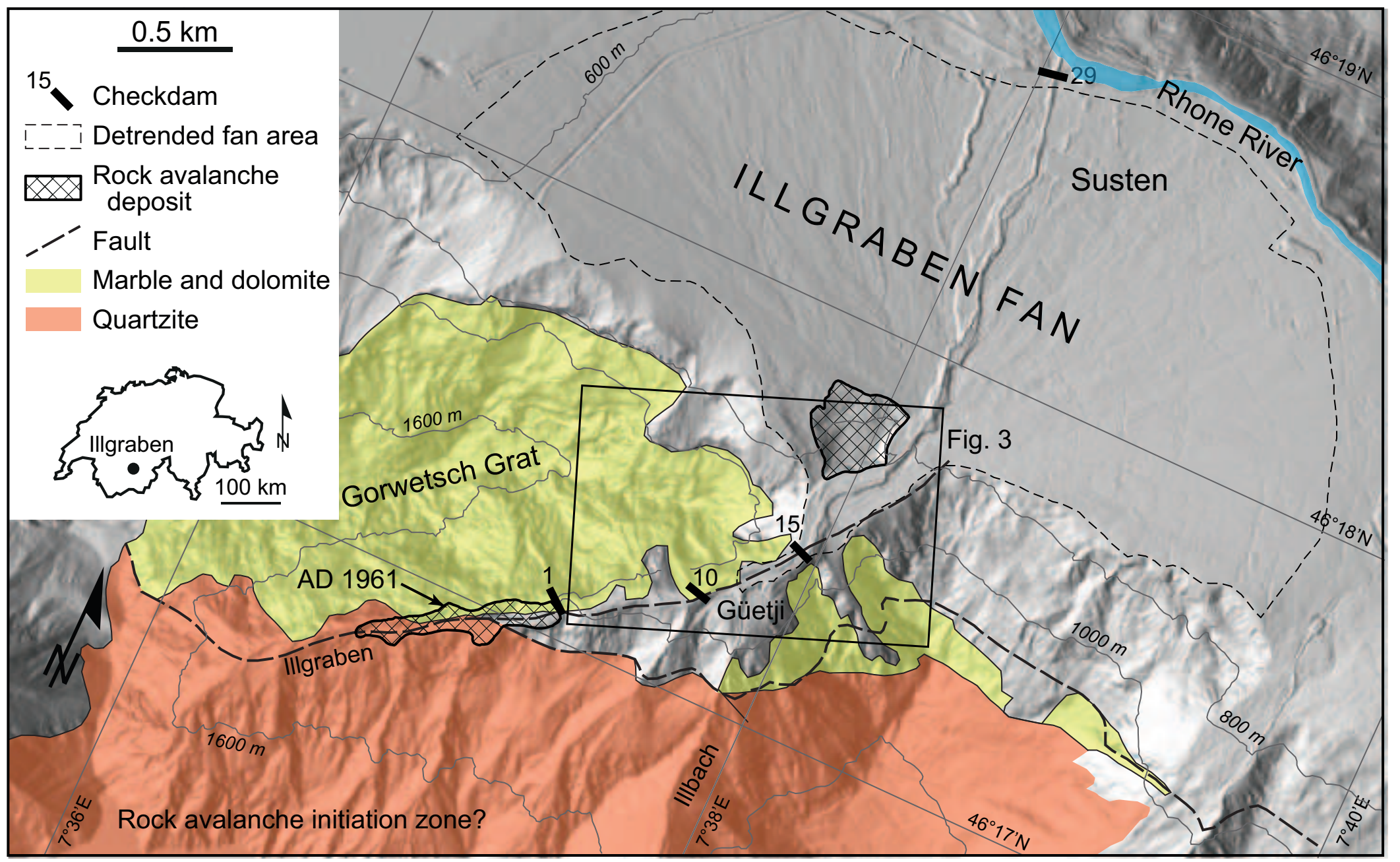

Figure 1. Overview of Illgraben catchment and fan system. Inset shows Illgraben location in southwestern Switzerland. Background hillshade image is derived from Swisstopo DTM-AV digital elevation model, with 2 m cell size. Extent of rock avalanche deposits in the IIlgraben catchment (emplaced in 1961) and at the head of the Illgraben fan (analyzed here) are shown in the cross-hatched pattern. Colors indicate extents of marble/dolomite and quartzite within the catchment, separated by an inactive fault; geology is simplified from Gabus et al. (2008). Selected checkdams, and their numbers, are shown by short black lines. Box shows location of Fig. 3 . 


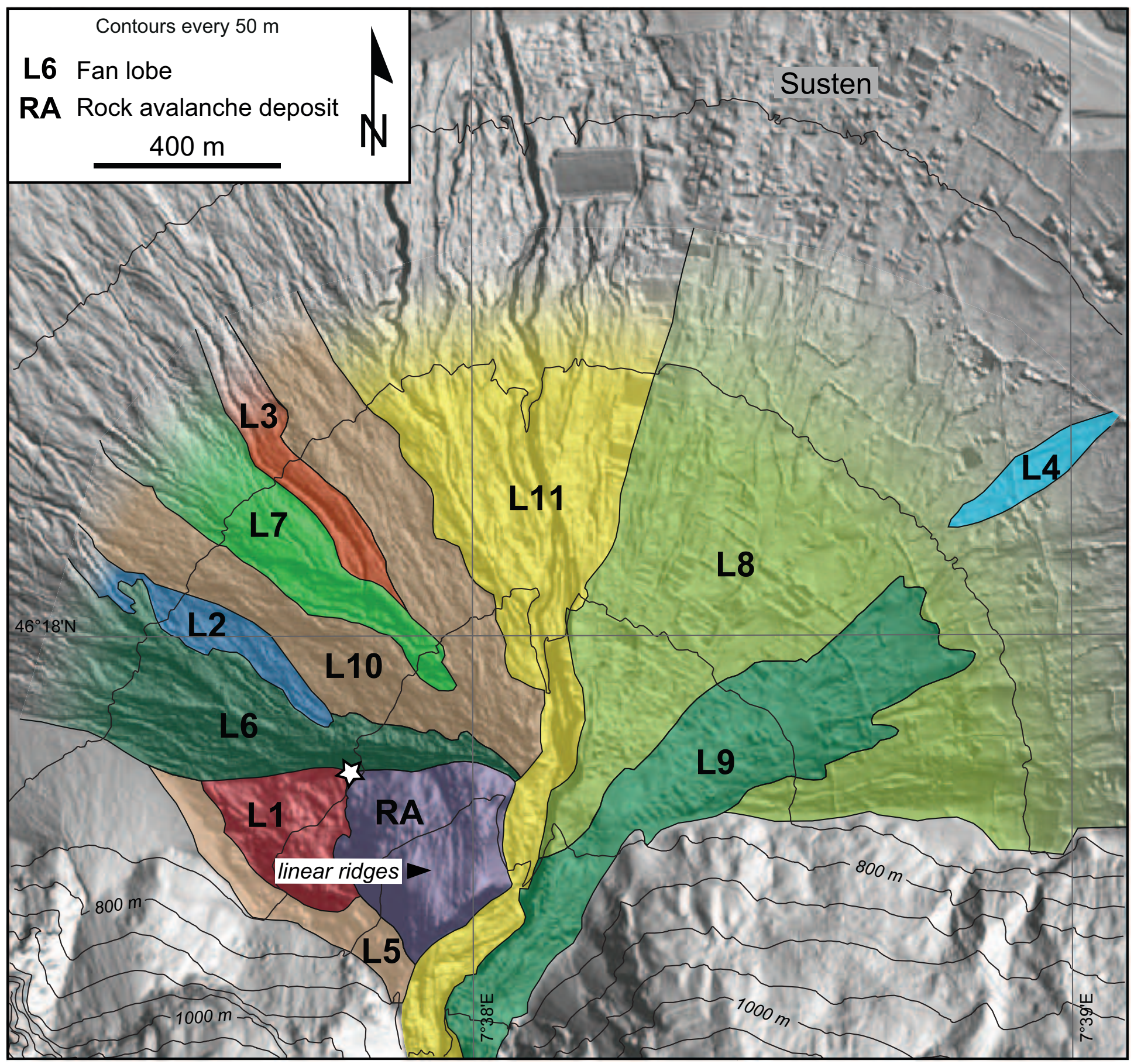

Figure 2. Depositional lobes on the Illgraben fan, as determined by field mapping cross-checked against the DTM-AV. Lobes are numbered in order of decreasing age, from L1 (oldest) to L11 (presently active). RA, rock avalanche deposit near fan apex. Note the linear ridges trending north-south on the surface of the rock avalanche. Star shows the lower elevation limit of the rock avalanche deposit at $748 \mathrm{~m}$ a.s.l., used for volume reconstruction. Cleared and levelled fields and buildings in the town of Susten are visible in the upper-right corner. 


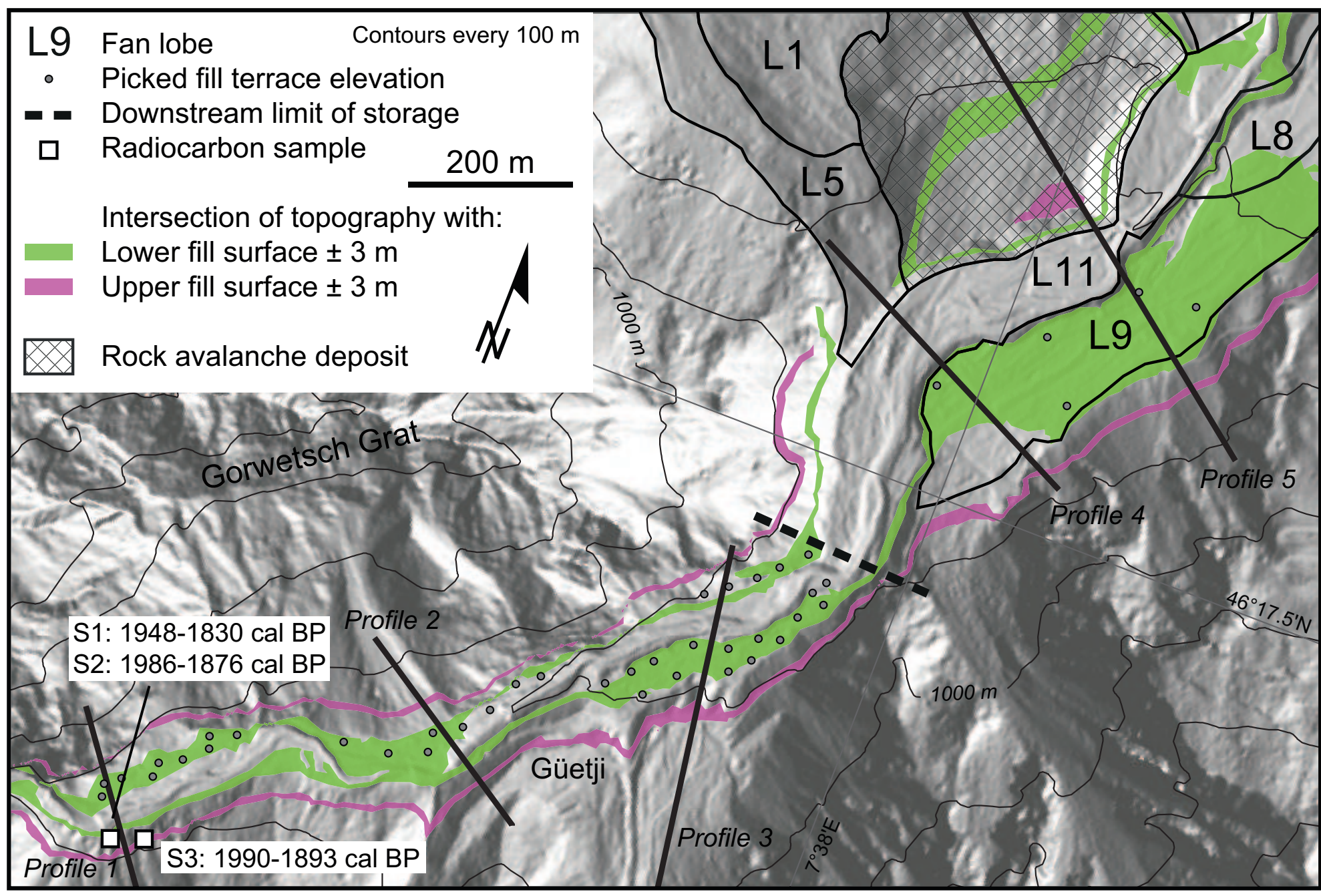

Figure 3. Relationships between sediment fill and rock avalanche deposit near the Illgraben fan apex. Rock avalanche deposit is shown in the cross-hatched pattern. The lower fill surface was interpolated from spot elevations on fill terraces and the coplanar lobe L9 on the Illgraben fan. The upper fill surface was constructed by shifting the lower fill surface upwards by $15 \mathrm{~m}$ to intersect the top of the rock avalanche deposit. Shaded areas show the intersection of topography with each fill surface, with a range of $\pm 3 \mathrm{~m}$ of elevation uncertainty. White squares show locations of radiocarbon samples S1-S3 from within fill on the right bank of the Illgraben channel. Dashed black line shows the downstream limit of fill terraces within the Illgraben catchment, taken as the downstream fill limit for calculation of sediment volumes. Solid black lines show the locations of profiles in Figure 4. 
m asl
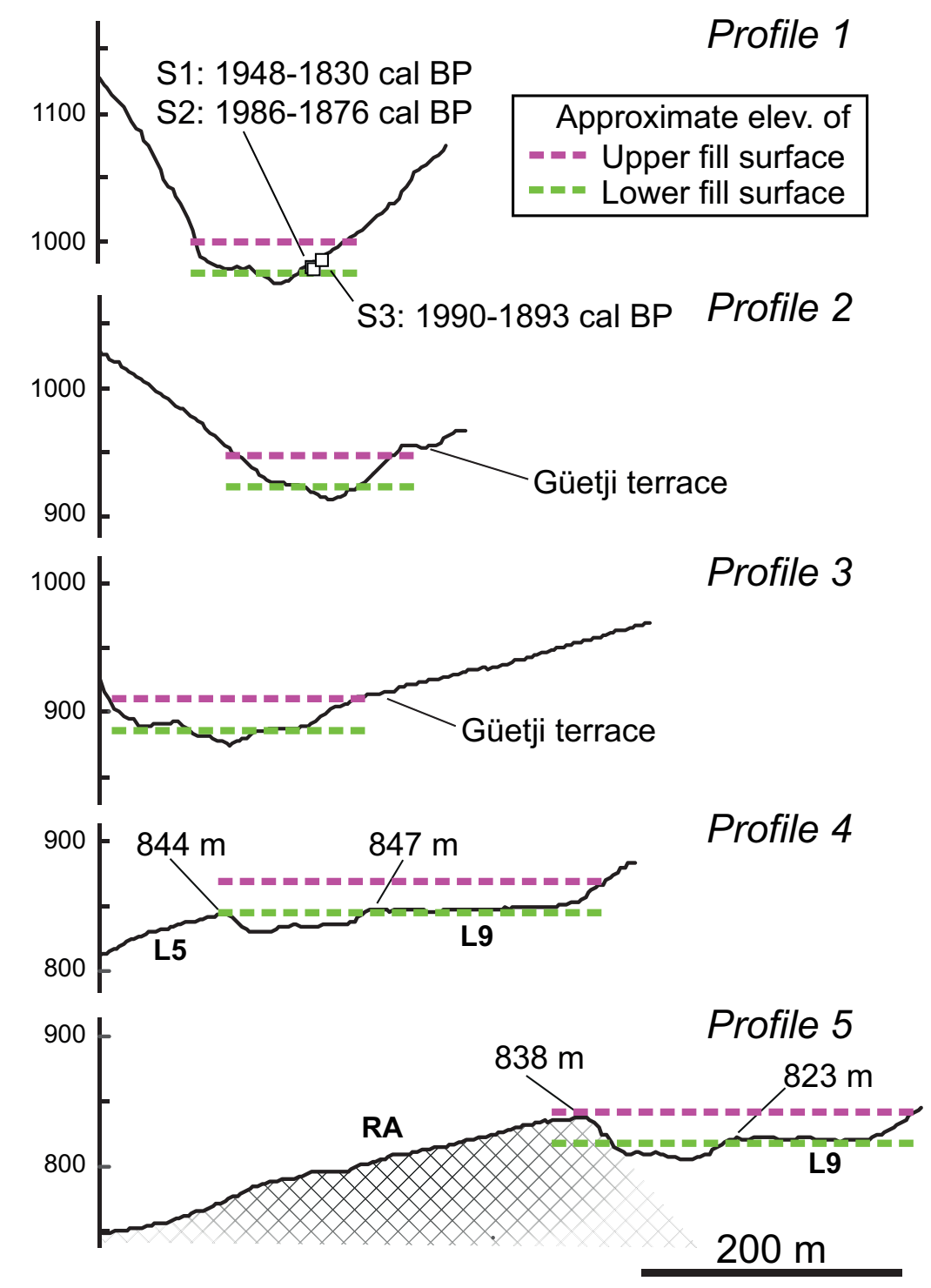

Figure 4. Topographic profiles across the Illgraben channel. See Figure 3 for locations. Profiles are oriented looking downstream (north to left), and are ordered from upstream (top) to downstream (bottom). Dashed lines show the elevation of the upper and lower fill surfaces at the position of each profile. White squares in profile 1 show the locations of radiocarbon samples S1-S3. The top of a prominent fill terrace at Güetji is shown in profiles 2 and 3. Profile 5 shows the topography of the rock avalanche deposit (RA), along with the upward shift of $15 \mathrm{~m}$ used to generate the upper surface from the lower surface. 


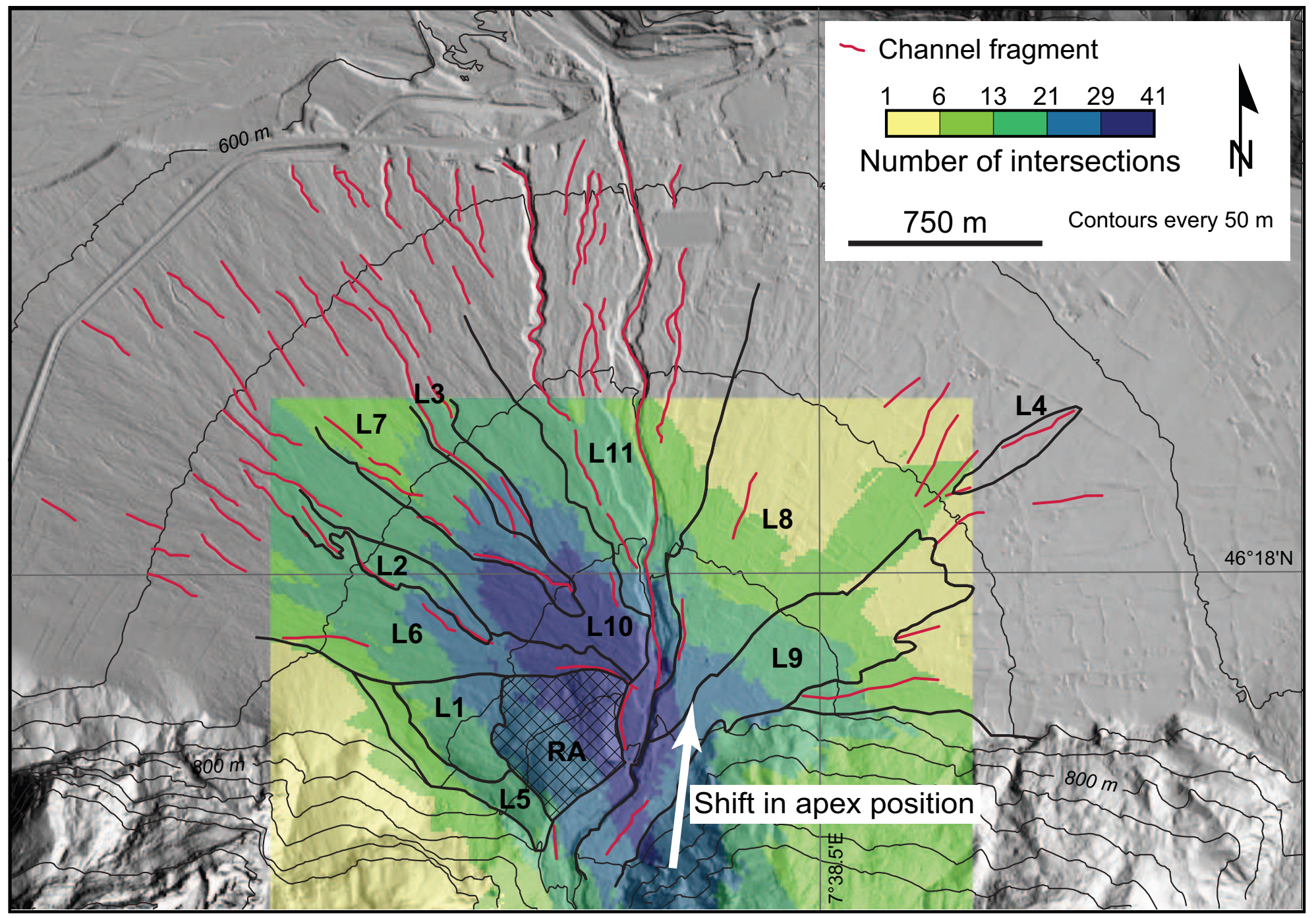

Figure 5. Fan apex reconstruction. Red lines show fragments of channels that were projected back toward the fan head to reconstruct the most likely apex position through time. Colors show the number of intersections between projected channel fragments; higher intersection numbers should correspond to likely fan apex positions. The highest intersection density is found just downstream of the rock avalanche deposit (RA), where lobes L6-L10 diverge toward the western sector of the fan. High intersection densities are also found to the south of this point, however, especially associated with channel fragments from lobes L2 and L3. This is consistent with a northward shift of $\sim 500 \mathrm{~m}$ in the fan apex, perhaps associated with emplacement of the RA. 


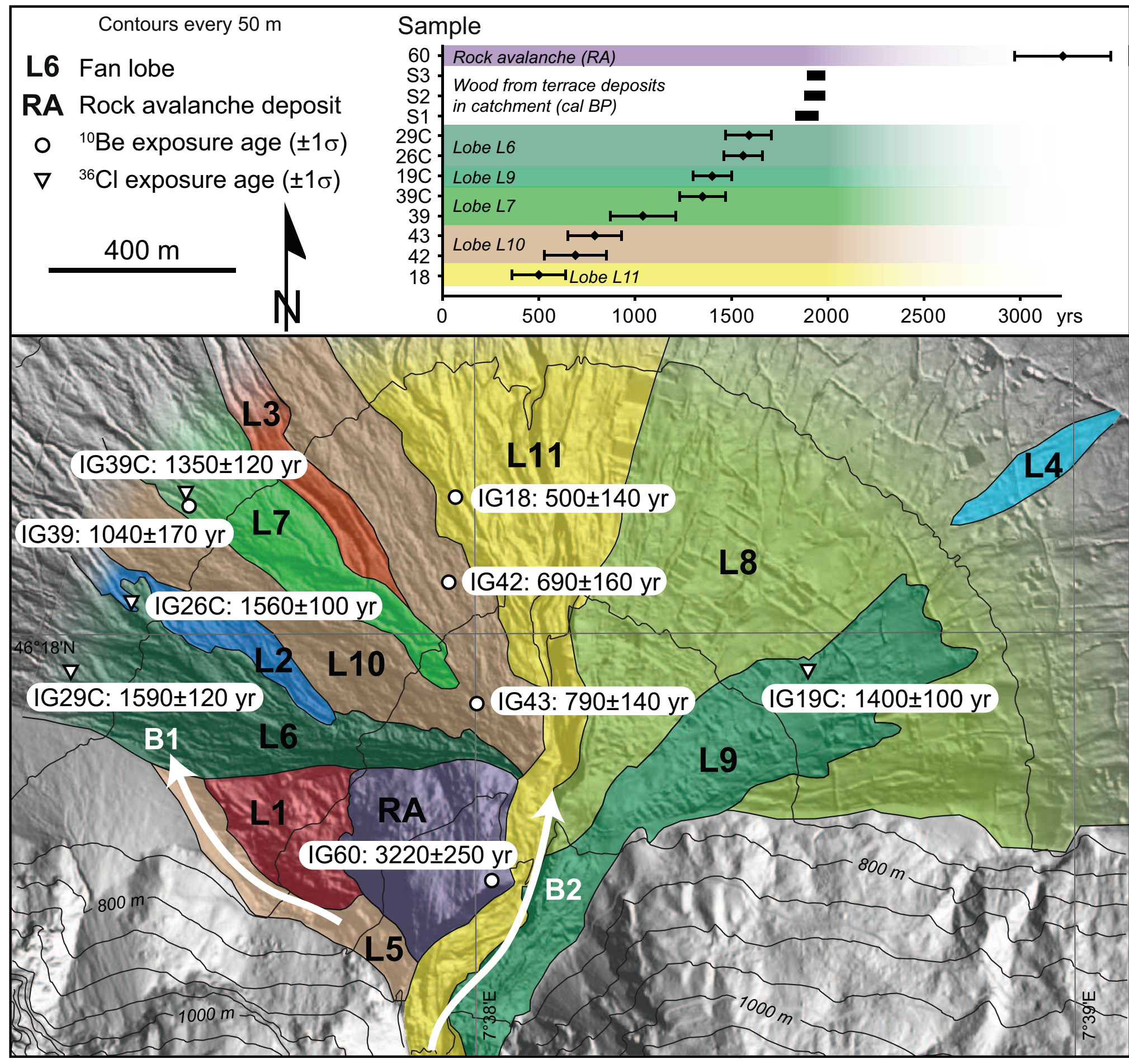

Figure 6. $10 \mathrm{Be}$ and $36 \mathrm{Cl}$ cosmogenic ages from the lllgraben fan. Lobes as in Figure 2. Ages are given with $\pm 1 \sigma$ uncertainties. See Tables 1 and 2 for analytical details. Upper-right panel shows ages ordered by depositional setting and relative lobe age, and also shows the radiocarbon ages from fill terrace samples in the catchment. B1 and B2 (white arrows) show alternative depositional pathways onto the fan. 


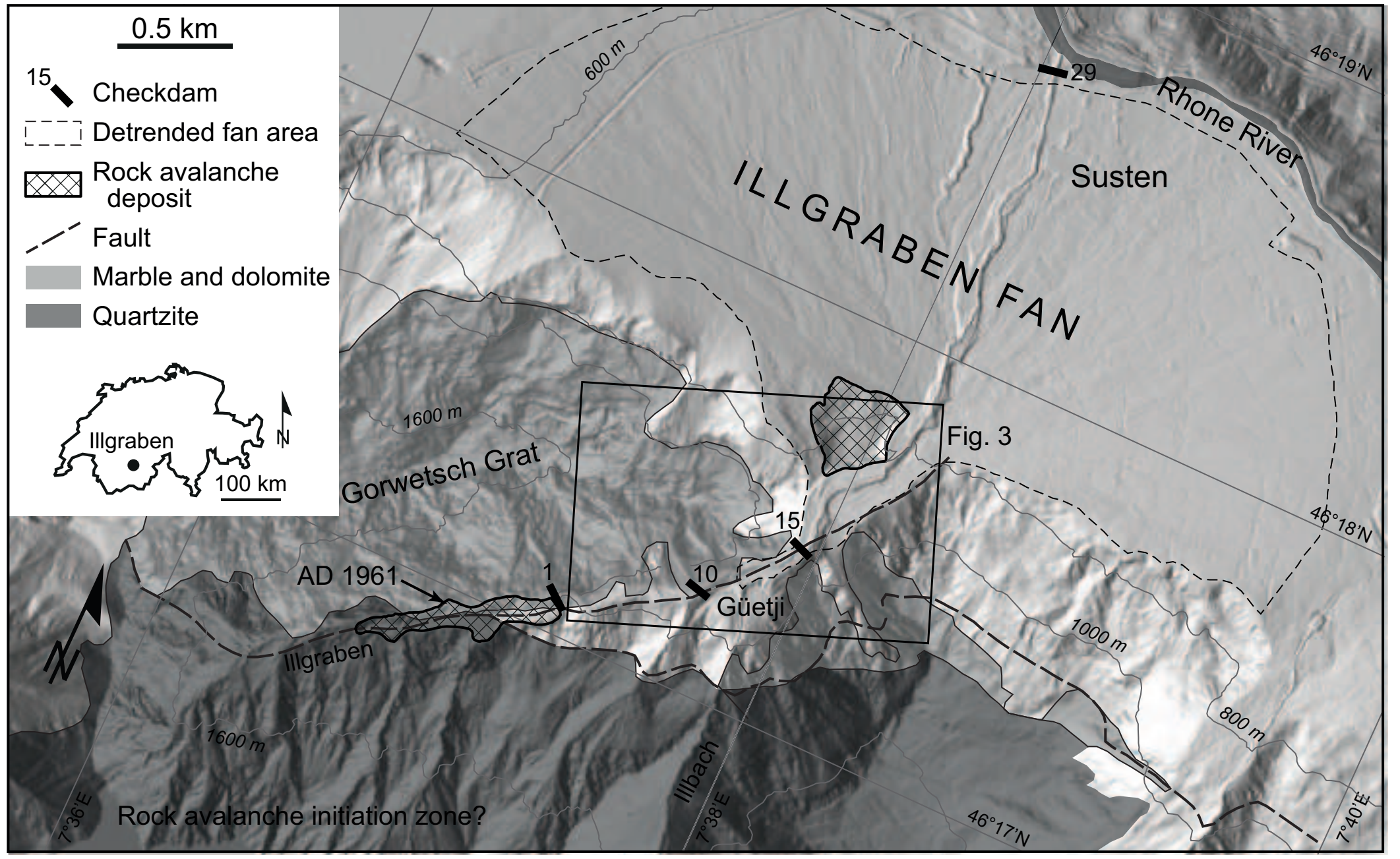

Figure 1. Overview of Illgraben catchment and fan system. Inset shows Illgraben location in southwestern Switzerland. Background hillshade image is derived from Swisstopo DTM-AV digital elevation model, with 2 m cell size. Extent of rock avalanche deposits in the IIlgraben catchment (emplaced in 1961) and at the head of the Illgraben fan (analyzed here) are shown in the cross-hatched pattern. Colors indicate extents of marble/dolomite and quartzite within the catchment, separated by an inactive fault; geology is simplified from Gabus et al. (2008). Selected checkdams, and their numbers, are shown by short black lines. Box shows location of Fig. 3 . 


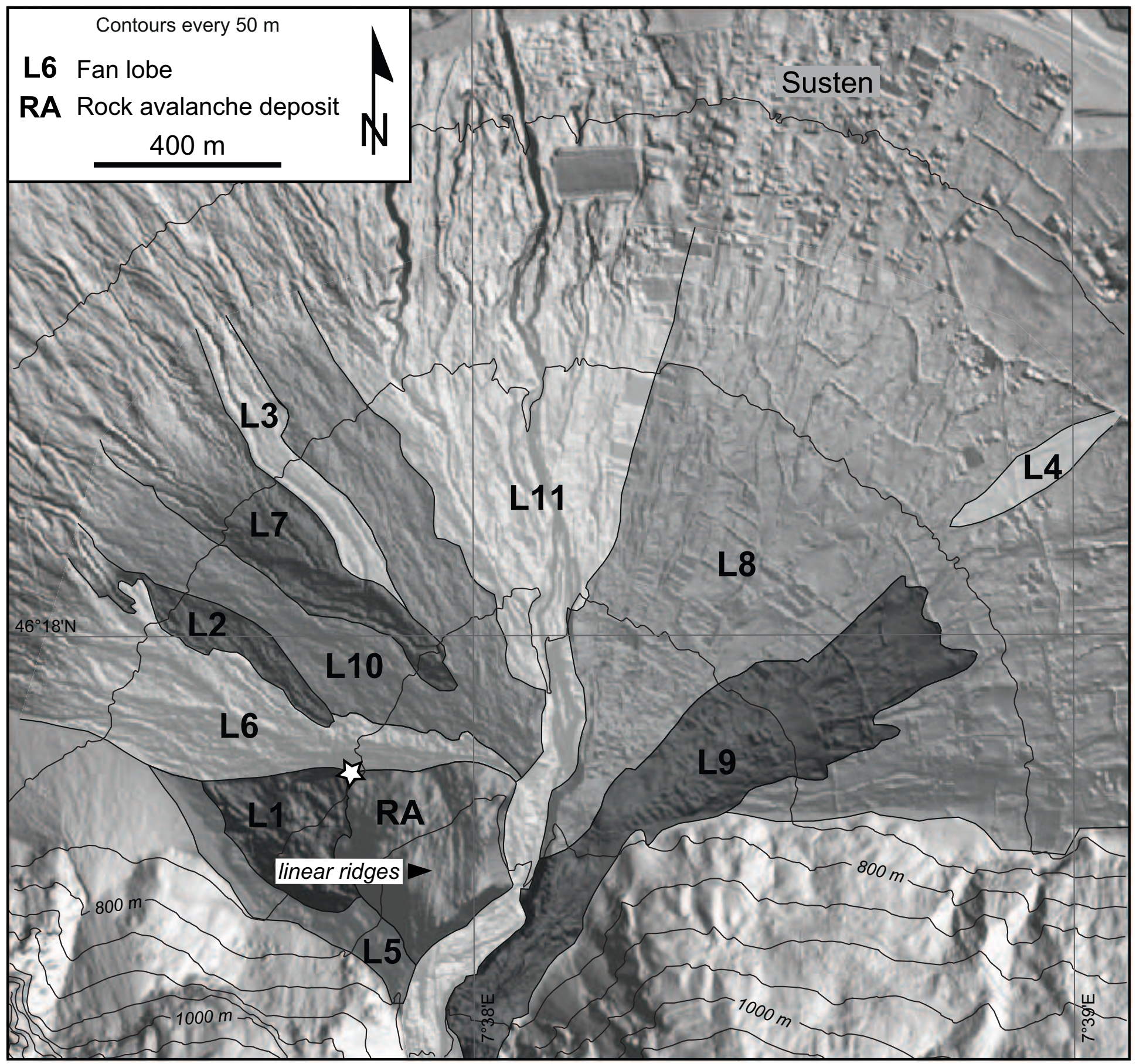

Figure 2. Depositional lobes on the lllgraben fan, as determined by field mapping cross-checked against the DTM-AV. Lobes are numbered in order of decreasing age, from L1 (oldest) to L11 (presently active). RA, rock avalanche deposit near fan apex. Note the linear ridges trending north-south on the surface of the rock avalanche. Star shows the lower elevation limit of the rock avalanche deposit at $748 \mathrm{~m}$ a.s.l., used for volume reconstruction. Cleared and levelled fields and buildings in the town of Susten are visible in the upper-right corner. 


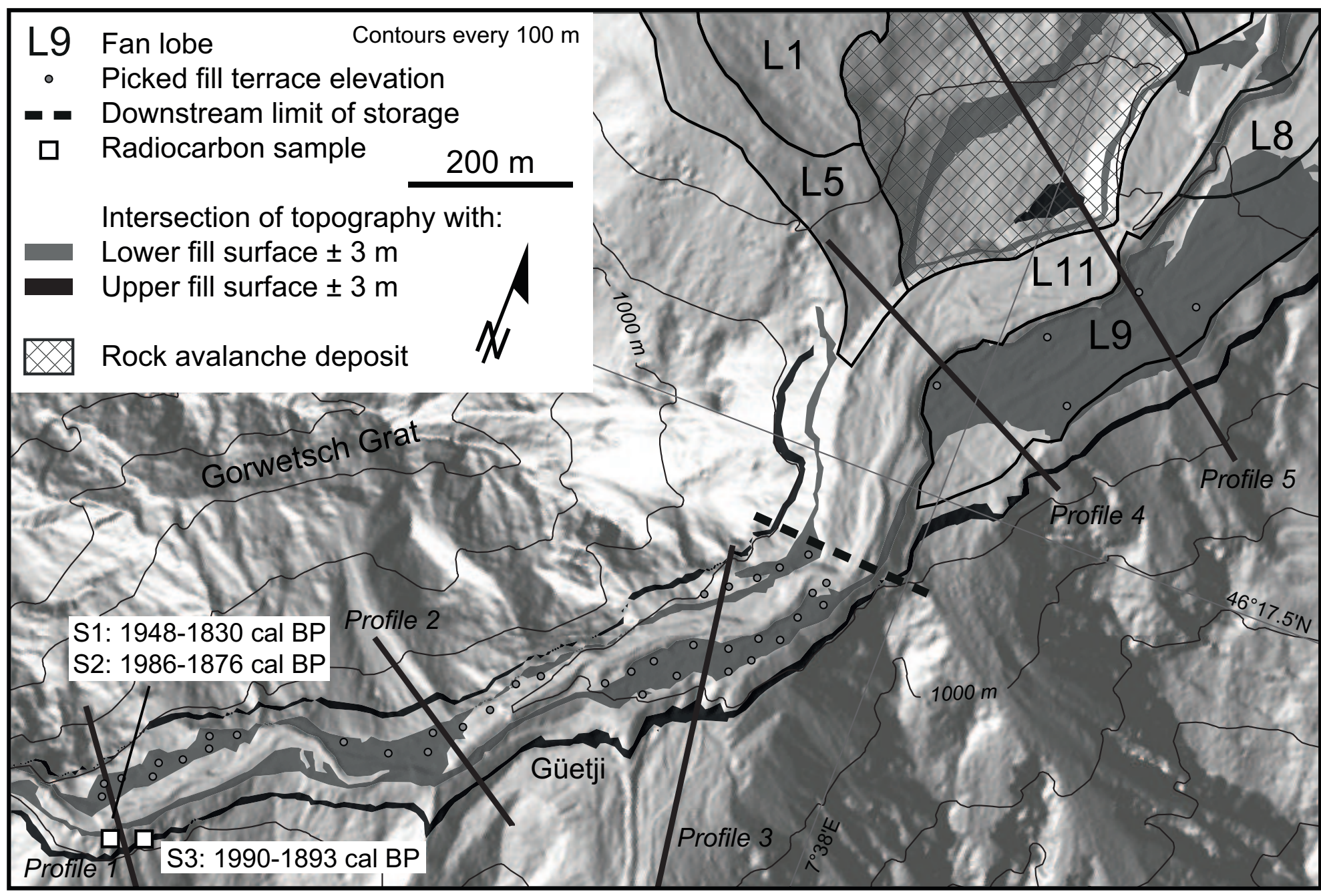

Figure 3. Relationships between sediment fill and rock avalanche deposit near the Illgraben fan apex. Rock avalanche deposit is shown in the cross-hatched pattern. The lower fill surface was interpolated from spot elevations on fill terraces and the coplanar lobe L9 on the Illgraben fan. The upper fill surface was constructed by shifting the lower fill surface upwards by $15 \mathrm{~m}$ to intersect the top of the rock avalanche deposit. Shaded areas show the intersection of topography with each fill surface, with a range of $\pm 3 \mathrm{~m}$ of elevation uncertainty. White squares show locations of radiocarbon samples S1-S3 from within fill on the right bank of the lllgraben channel. Dashed black line shows the downstream limit of fill terraces within the Illgraben catchment, taken as the downstream fill limit for calculation of sediment volumes. Solid black lines show the locations of profiles in Figure 4. 
m asl

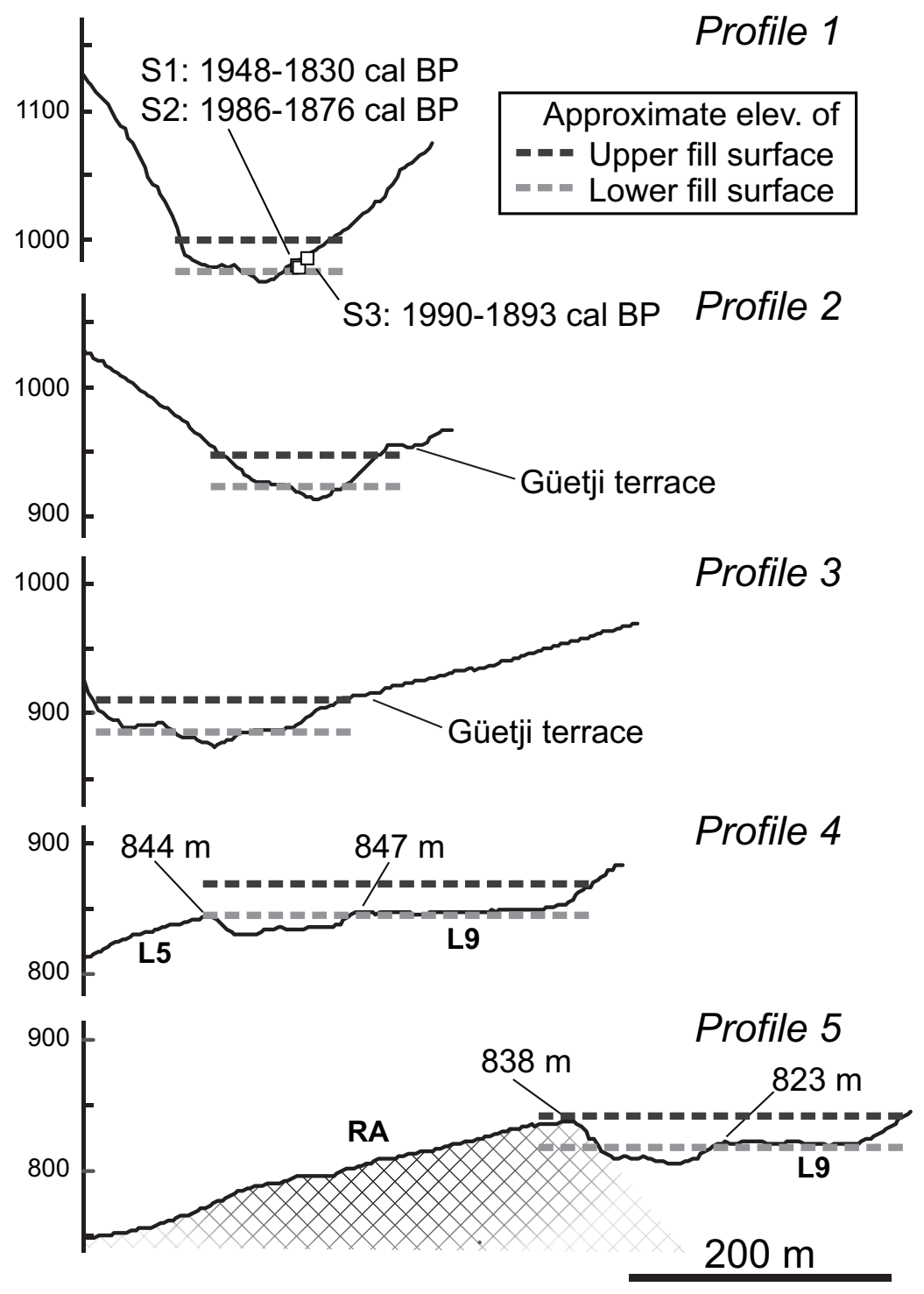

Figure 4. Topographic profiles across the Illgraben channel. See Figure 3 for locations. Profiles are oriented looking downstream (north to left), and are ordered from upstream (top) to downstream (bottom). Dashed lines show the elevation of the upper and lower fill surfaces at the position of each profile. White squares in profile 1 show the locations of radiocarbon samples S1-S3. The top of a prominent fill terrace at Güetji is shown in profiles 2 and 3. Profile 5 shows the topography of the rock avalanche deposit (RA), along with the upward shift of $15 \mathrm{~m}$ used to generate the upper surface from the lower surface. 
Contours every $50 \mathrm{~m}$

L6 Fan lobe

RA Rock avalanche deposit

- ${ }^{10} \mathrm{Be}$ exposure age $( \pm 1 \sigma)$

$\nabla \quad{ }^{36} \mathrm{Cl}$ exposure age $( \pm 1 \sigma)$

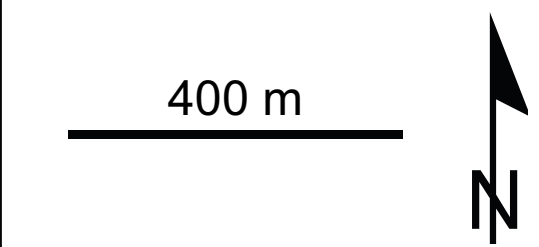

\section{Sample}

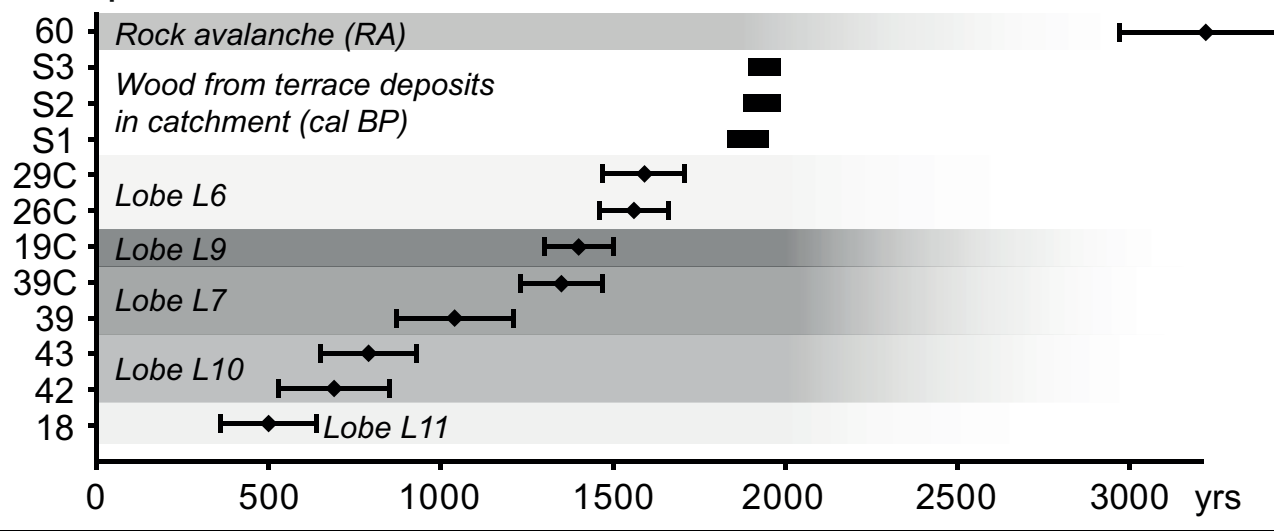

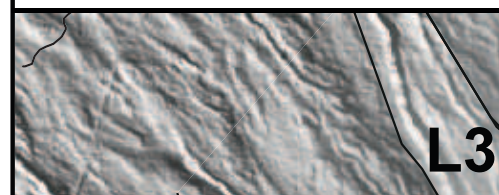

N IG39C: $1350 \pm 120 \mathrm{yr}$

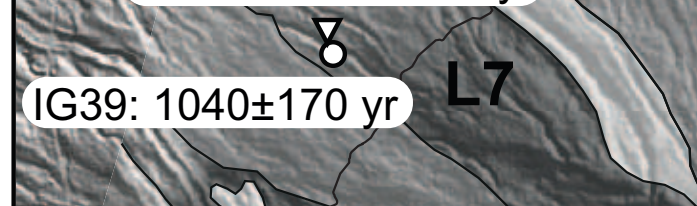

46918

IG26C: $1560 \pm 100 \mathrm{yr}$

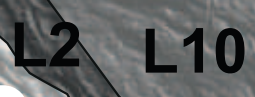
L10

IG29C: $1590 \pm 120 \mathrm{yr}$ L6 o IG43: $790 \pm 140 \mathrm{yr}$

IG42: $690 \pm 160 \mathrm{yr}$

IG18: $500 \pm 140 \mathrm{yr}$

L11

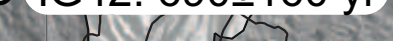

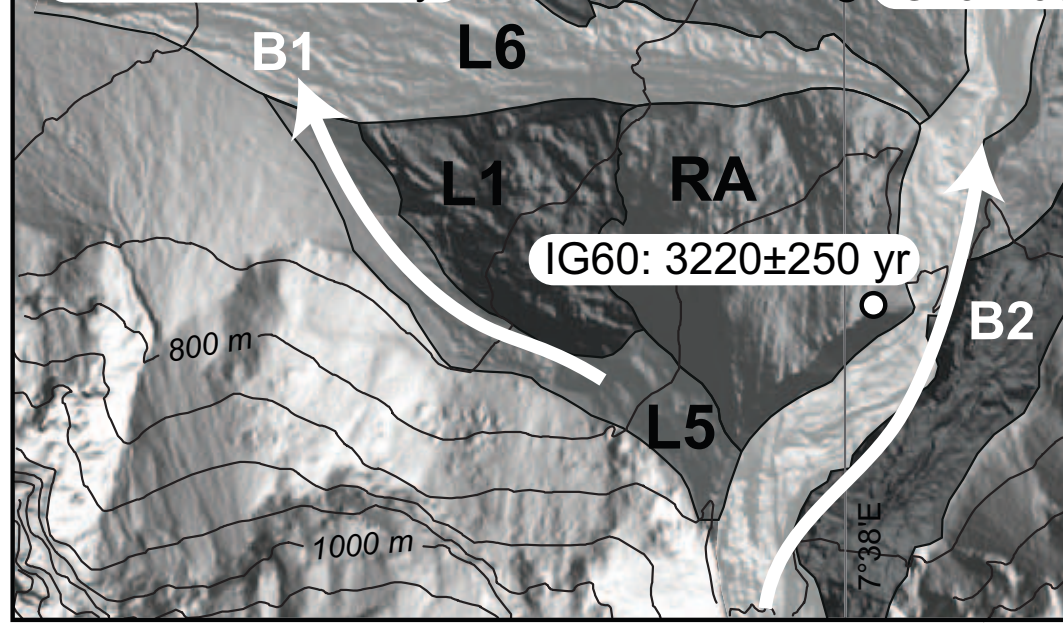

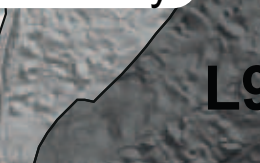

IG19C: $1400 \pm 100 \mathrm{yr}$

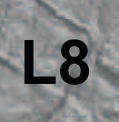

Figure 6. 10Be and $36 \mathrm{Cl}$ cosmogenic ages from the Illgraben fan. Lobes as in Figure 2. Ages are given with $\pm 1 \sigma$ uncertainties. See Tables 1 and 2 for analytical details. Upper-right panel shows ages ordered by depositional setting and relative lobe age, and also shows the radiocarbon ages from fill terrace samples in the catchment. B1 and B2 (white arrows) show alternative depositional pathways onto the fan. 